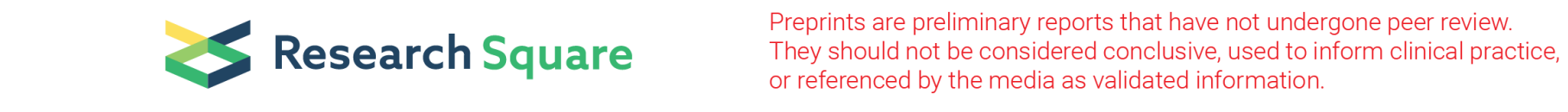

\title{
Health-Care Equity in Indonesia
}

\section{Robert Arthur Simanjuntak} \\ Universitas Indonesia \\ Benedictus Raksaka Mahi \\ Universitas Indonesia \\ Riatu Qibtiyyah \\ Universitas Indonesia
}

Iman Sufrian ( $\sim$ sufrian@yahoo.com )

University of Indonesia https://orcid.org/0000-0002-6539-7358

Research

Keywords: Health care, Decentralization, Economic Crisis, Equity- Decomposition, Theil index, Indonesia

Posted Date: March 9th, 2020

DOI: https://doi.org/10.21203/rs.3.rs-16470/v1

License: (c) (i) This work is licensed under a Creative Commons Attribution 4.0 International License.

Read Full License 


\title{
Health-Care Equity in Indonesia
}

\author{
Iman Sufrian ${ }^{1 *}$, Robert Arthur Simanjuntak ${ }^{2}$, Benedictus Raksaka \\ Mahi ${ }^{3}$, Riatu Qibtiyyah ${ }^{4}$
}

\begin{abstract}
Purpose: The health-care equity has been adopted as the principle in the health system in Indonesia since the enactment of Law No. 40 of 2004 concerning the National Social Security System. This study evaluates the achievement of health-care equity in Indonesia and investigates the spatial dimension of inequity by using a measure of inequity that can be decomposed completely into the Theil index. Third, this study conducts a before and after comparison of the change in the degree of decentralization in Indonesia. Besides, this study also conducts a period with economic crisis and period without economic crisis comparison for within-area health-care inequity.
\end{abstract}

Design/methodology/approach: The secondary cross-sectional data originate from the Indonesian Socio-Economic Surveys (NSES) of 1996, 1998, 2000, 2002, 2005, 2008, 2011, and 2014. The Theil index was used to describe the inequity in health care. Subsequently, the Theil index is decomposed into between- and within-region at the province and district level. This paper compares health-care equity before and after decentralization in Indonesia. This paper also compares the health-care equity between periods with and without an economic crisis in Indonesia.

Findings: The Theil index of health-care inequity provides an initial description that there was an improvement of equity in health care in 1996-2014. However, findings suggest the health-care inequity had worsened during the economic crisis of 1998 despite improved health-care equity, especially during the second phase of decentralization in the period of 2005-2014.

Value/Originality: The findings suggest that an increase in the degree of decentralization in Indonesia is associated with a lower degree of overall, within-province, within-district and between-district inequity in both outpatient health care and inpatient health care. In addition, the 
economic crisis is related to higher overall, within- and between-region health-care inequities.

Keywords - Health care Decentralization· Economic Crisis· Equity-

Decomposition· Theil index Indonesia

Paper type Research paper

\footnotetext{
${ }^{1}$ University of Indonesia, Department of Economics (Depok, Indonesia). E-mail: sufrian@yahoo.com

${ }^{2}$ University of Indonesia, Department of Economics (Depok, Indonesia). E-mail: rob 7762@yahoo.co.uk

${ }^{3}$ University of Indonesia, Department of Economics (Depok, Indonesia). E-mail: raksakamahi@yahoo.com

${ }^{4}$ University of Indonesia, Department of Economics (Depok, Indonesia). E-mail: prcrmqx@gmail.com

${ }^{*}$ Correspondence : sufrian@yahoo.com
} 


\section{Introduction}

Health-care equity is a goal in the health system in various countries (O'Donnell, van Doorslaer, Wagstaff, \& Lindebow, 2008). Indonesia has adopted the principle of equity in health care in its health system since the enactment of Law No. 40 of 2004 concerning the National Social Security System. Therefore, it is important to evaluate and monitor the achievement of health-care equity.

There have been ample researches that analyze the achievement of healthcare equity. The method applied for this specific research is also well established. Usually, this type of research focuses on single country research. The concentration index is commonly used to analyze the achievement of health-care equity. This type of research usually evaluates the socio-economic related health-care inequity. The type of health-care used for this type of research is also varied from general health care, specific health care. This type of study also varied regarding the focus on sample studies ranging from on a specific group of populations to the general population. Some studies try to link the health-care equity with certain policy, usually social insurance program although such study do not provide a causal relationship evidence (Ngrin, Pinilla, \& Abasolo, 2019; Nunez \& Chi, 2013; Park, 2016; Phiri \& Ataguba, 2014; Quinonez \& Grooterndorst, 2011; Robards, et al., 2019; Hidayat, Thabrany, Dong, \& Sauerborn, 2004; Maharani D. A., 2009; Maharani \& Rahardjo, 2012). Studies that evaluate the achievement of equity dimension performance in Indonesia are limited. (Hidayat, Thabrany, Dong, \& Sauerborn, 2004) evaluated the effect of compulsory health insurance on health-care equity (outpatient health care) in Indonesia. They used data from the 1997 Indonesian Family Life Survey data (IFLS). Their findings indicated that inequity in outpatient care existed in Indonesia. They also concluded that access to outpatient health care received a solid positive impact from 
mandatory insurance (PT ASKES and PT JAMSOSTEK insurance program). Despite the positive impact of PT ASKES and PT JAMSOSTEK insurance on health-care equity, the outcomes remained tentative due to only a year dataset is utilized. Another study was conducted by (Maharani D. A., 2009) pertaining to the inequity in dental care utilization in Indonesia, using Indonesia Socioeconomic Survey (NSES) data in 2004. She concluded that the inequity of dental care utilization existed in Indonesia. (Maharani \& Rahardjo, 2012) also evaluated the equity aspect of dental health care. Their study also utilized the Indonesian Socioeconomic Survey data, but the data spanned from 1999 to 2009 . The study concluded that dental health-care inequity existed in Indonesia. The positive value of the concentration index indicated that the utilization of dental health care was concentrated among the higher socioeconomic status (SES) group.

All studies mentioned above apply the concentration index as a measurement of inequity. The concentration index is able to capture the socio-economic gradient of inequity. However, (Zhong, 2010) criticized the use of the concentration index. He stated that need factors were the only justifiable reason for inequality in health-care utilization. Other factors include social-economic factors and location of residence also cause inequality of the health-care utilization. These latter factors are seen as the source of health-care inequity. Therefore, neither pro-rich nor propoor inequities have any a priori ethical arguments (Zhong, 2010). ${ }^{1}$

\footnotetext{
Socioeconomic factors such as education level, income and location of residence are factors that cause health-care inequity. These factors are the source of unjustifiable reasons for inequality in health-care utilization. Existing researches generally uses the concentration index as a measure of inequality in health services. The concentration index provides an overview of the use of health services based on socioeconomic groups (generally based on income groups). The value of the concentration index ranges from -1 to 1 . Negative values indicate that inequality in health services is pro-poor. While positive values indicate inequality in health services in favor of the rich (pro rich). This was criticized by Zhong (2010) who stated that inequality pro poor and pro rich are equally undesirable conditions. The use of concentration indexes has complex policy implications. Different when we look at income inequality, the implication is to redistribute some of the income of the rich to the poor through progressive taxes. But this cannot be applied to health services. Pro rich
} 


\section{Aims}

This study re-examines the health-care equity achievement in Indonesia, more specifically, to provide an evaluation of the achievement of healthcare equity in Indonesia and to analyze the spatial dimension of inequity in province and district levels. We extend previous studies in four aspects. First, we evaluate the achievement of overall curative health care (not only specific health care such as dental health care but also health care in general). Second, this study also analyzes the spatial dimension of inequity, using the Theil index to measure health-care equity for curative health care in general, by dividing into two groups of health care, outpatient and inpatient health care. The Theil index is more appealing than the concentration index because this inequality measure is perfectly decomposable into within-area and between-area components devoid of the error term (Zhong, 2010). The decomposition of the Theil Index into within-area and between-areas at both province and district levels provides more insight into the source of inequity from the spatial dimension. Third, this study compares before and after the degree of decentralization in Indonesia. Lastly, this study identifies a period with and without economic crisis periods for within-area health-care inequity. Although the above comparisons may not fully reflect causal relationships, they may still shed some light on this relationship.

\section{The method, variables, and data}

\section{Method}

\section{Indirect need standardization}

Defining equity is a distinct issue in the research of health-care inequity. The definition of equity in this study is elicited on a horizontal

inequality does not imply redistribution of health services to the poor or vice versa. Ethically, differences in the treatment of health services can only be accepted when there are differences in needs. 
inequities analysis which is the same as that of (Zhong, 2010). Horizontal equity is achieved if persons with commensurate needs of medical treatment accept the same quantity of treatment (Wagstaff \& van Doorslaer, 2000). The measurement of equity is defined as the fairness gap (Fleurbay \& Schokkaert, 2009). The fairness gap in health care is the distance between the actual utilization of health care and health-care needs. To estimate the fairness gap, this study employs the approach of indirect standardization of need that (Wagstaff \& van Doorslaer, 2000)proposed and can be calculated as:

$m_{i j t}^{I S}=\left(m_{i j t}-\widehat{m}_{i j t}\right)+\bar{m}$

where $m_{i j t}$ is the actual health-care utilization of individual $\mathrm{i}$ in province $\mathrm{j}$ at period $\mathrm{t}, \widehat{m}_{i j t}$ is the measure that is adjusted with needs for health-care utilization of individual $\mathrm{i}$ in province $\mathrm{j}$ at period $\mathrm{t}$ and $\bar{m}$ is the sample mean of the measure of health- care utilization.

Two steps are required to compute the measure of health-care utilization that is need-adjusted $\left(\widehat{m}_{i j t}\right)$. First, we conduct a negative binomial regression that elucidates the health care utilization of all individuals in the sample, with an array of explanatory variables. This study uses a regression equation such as the following model:

$m_{i j t}=\alpha+\sum_{k} \beta_{k} X_{k i j t}+\sum_{p} \gamma_{p} Z_{p i j t}+\varepsilon_{i}$

which distinguishes between two sorts of explanatory variables: a span of $k$ need indicator variables for instance, demographic and morbidity variables $\left(X_{k}\right)$, and $p$ other non-need variables such as level of education, expenditure per capita, and place of domicile $\left(Z_{p}\right)$. The list of variables is presented in the appendix (Table 1). $\alpha, \beta$ and $\gamma$ serve as parameters and $\varepsilon_{i}$ stands as an error term. In the subsequent stage, the value of the non-need variables are set at the sample mean values and 
forecast $\widehat{m}_{i j t}$ with real values of the need variables as follows:

$\widehat{m}_{i j t}=\hat{\alpha}+\sum_{k} \hat{\beta}_{k} X_{k i j t}+\sum_{p} \hat{\gamma}_{p} \bar{Z}_{p i j t}$

The approximated parameters in the second stage of the above formula are $\hat{\alpha}, \widehat{\beta}$, and $\hat{\gamma}$. The individual receives $\widehat{m}_{i j t}$ amount of health care if she/he is to be treated averagely the same as others with identical needs characteristics. Drew on the value of $\widehat{m}_{i j t}$, one is able to calculate the fairness gap represented by $m_{i j t}^{I S}$. If every individual's value of actual health-care utilization $m_{i j t}$ corresponds with the needadjusted value of health-care utilization $\widehat{m}_{i j t}$, the value $\bar{m}$ would be on a par with any calculated measures of inequity. Such a condition is therefore concluded as perfect equity.

The study employs health care utilization measure, which is the number of a specific health care appointment in the past 1 month and 12 months as (Zhong, 2010) suggests. Since the dependent variables are subtle and non-normally distributed, the OLS becomes an unsuitable estimation method. What is also customary in health data is "over dispersion"that refers to a condition when the distribution variance surpasses the mean. Jones (2000) insinuates an outline of the econometric methods that have been applied to this type of count data. As per (Van Doorslaer, Koolman, \& Jones, 2004; Jones, 2000; Zhong, 2010), when the dependent variable is a quantitative measure of health care utilization with "over dispersion", the generalized negative binomial model performs well. Therefore, this study also adopts the generalized negative binomial model.

\section{Theil index}

The generalized entropy (GE) class is the only inequality measure that 
has perfect decomposability property (Cowell, 2000). Theil's measure of inequality is one of the most well-known GE class inequality (Theil, 1967). The Theil index is calculated as follows:

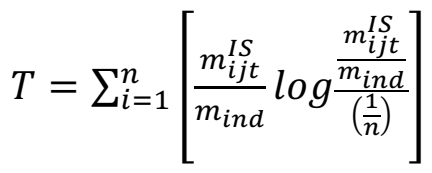

Eq. 4 above contains the number of individuals in Indonesia as represented by $n$, the fairness gap $\left(m_{i j t}^{I S}\right)$ of the health-care measure of individual $i$ in province $\mathrm{j}$ and period $\mathrm{t}$, and the total number of fairness gap of the outpatient health care and inpatient health care in Indonesia $\left(\mathrm{m}_{\text {ind }}\right)$ on period $\mathrm{t}$. The degree of overall inequity in health care in Indonesia is represented in $T$. If the fairness gap of every individual's health is on a par with $\bar{m}, T$ becomes zero in value. There are two group components in the Theil index, they are a betweengroup and within-group components without error term (Zhong, 2010). In the context of this study, $T$ can be expressed in the following equation:

$T=T_{B}+T_{w}=\sum_{i=1}^{n}\left[\frac{m_{i j t}^{I S}}{m_{\text {ind }}} \log \frac{\frac{m_{i j t}^{I S}}{m_{\text {ind }}}}{\frac{n_{i}}{n}}\right]+\sum_{j=i}^{n} w_{j} T_{j}$

The value of $T_{B}$ in the above equation represents between region (province or district) inequity and $T_{w}$ is the within-region (province or district) inequity in health-care utilization. Eq. 5 has $T_{B}$ as the first term, $n$ as the number of provinces/districts in Indonesia, $\mathrm{m}_{\mathrm{ijt}}{ }^{\mathrm{IS}}$ as the total number of indirectly need-standardized health care in region $j$, and $n_{j}$ as the number of individuals in region $j . T_{w}$ serves as the second term in the second part of Eq. 5 and is a weighted sum of the Theil index for each province or district. The weight $w_{j}$ equals $\frac{m_{i j t}^{I S}}{m_{i n d}}$ and the 
calculation of $T_{j}$ can be performed similarly to that of Eq. 4 .

Theil index is a measure that can reflect the structural difference in the distribution of the health care variable amidst groups from the distribution of population amongst those same groups. $T_{B}$ reaches zero (minimum) when each province/district has an identical share of healthcare utilization and share of the population. $T_{W}$ reaches its minimum (zero) when the share of health care for each individual $\left(\frac{m_{i j t}^{I S}}{m_{i n d}}\right)$ is the same as $l / n$ (Conceicao \& Ferreira, 2000).

\section{Variables and data}

This study uses the inequity indices for the fairness gap of two health care groups (inpatient and outpatient health care) at eight different periods: 1996, 1998, 2000, 2002, 2005, 2008, 2011, and 2014. Those indices are then decomposed into within-province and between-province and also within-district and between-districts. Table 1 (Appendix) presents the definitions of variables utilized in the indirectly needstandardization method. The choice of explanatory variables in this study is similar to that of (Zhong, 2010). The data for the eight periods in this study derive from 1996, 1998, 2000, 2002, 2005, 2008, 2011, and 2014 National Socio-economic Survey.

\section{Results}

The first part of this result shows the use of health care in Indonesia during the 1996-2014 period. The measures used for health care in this study are outpatient health care and inpatient health care. The health-care utilization is proof that an individual has access to health care. Figure 1 and figure 2 suggest that access to health care has been improving in 
Indonesia. The 1996 economic crisis was the exception, especially for outpatient health care. However, the inequality of health care utilization does not completely reveal the health-care inequity. To measure inequity, inequality in the utilization of health care must be standardized for differences in need. Any residual inequality in utilization after standardization is interpreted as horizontal inequity (O'Donnell, van Doorslaer, Wagstaff, \& Lindebow, 2008).

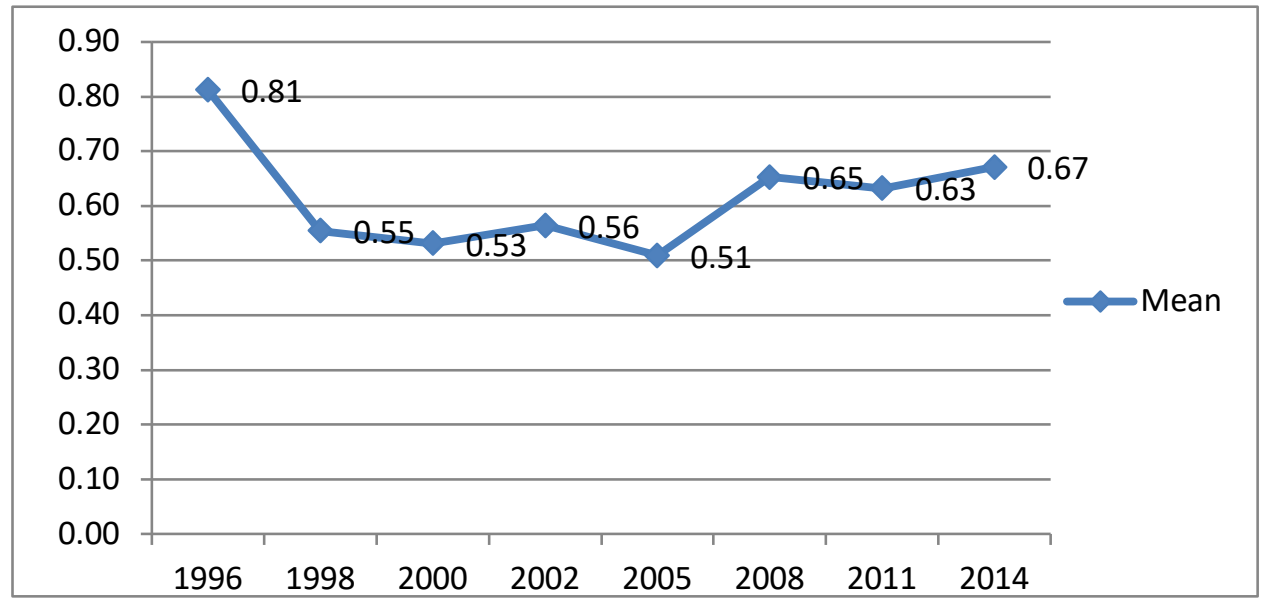

Utilization of Outpatient Health Care in Indonesia

Figure 1. Average Utilization of Outpatient Health Care (Number of Visits) Per Individual

Utilization of Inpatient Health Care in Indonesia

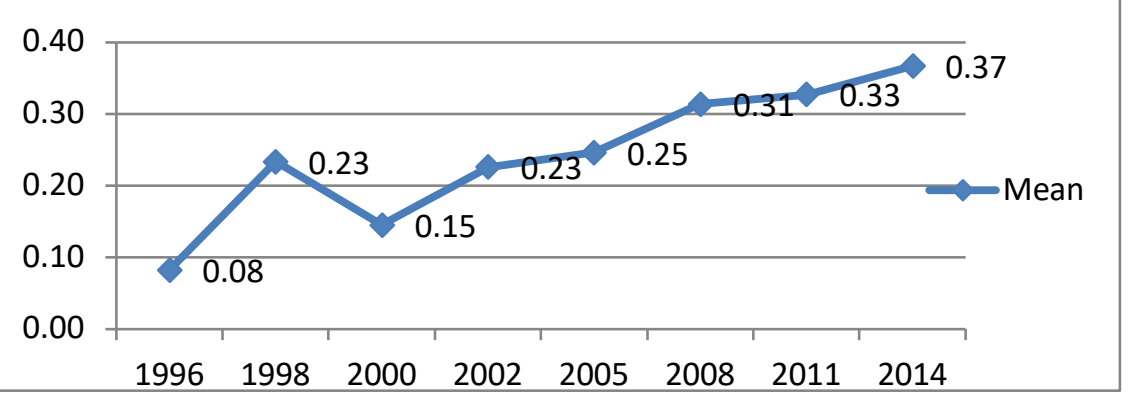


Figure 2. Average Utilization of Inpatient Health Care (Days Spent) Per Individual

Inequity in Health Care in Indonesia (1996-2014)

Figures 3 to 12 show the dynamics of outpatient health-care inequity and inpatient health-care inequity in Indonesia during the period 1996 - 2014. These health-care inequities include total inequality, within-regions inequities, and between-regions inequity. Inequity decomposition is based on district/city level and provincial level.

The Inequity of Outpatient Health Care in Indonesia (1996-2014)

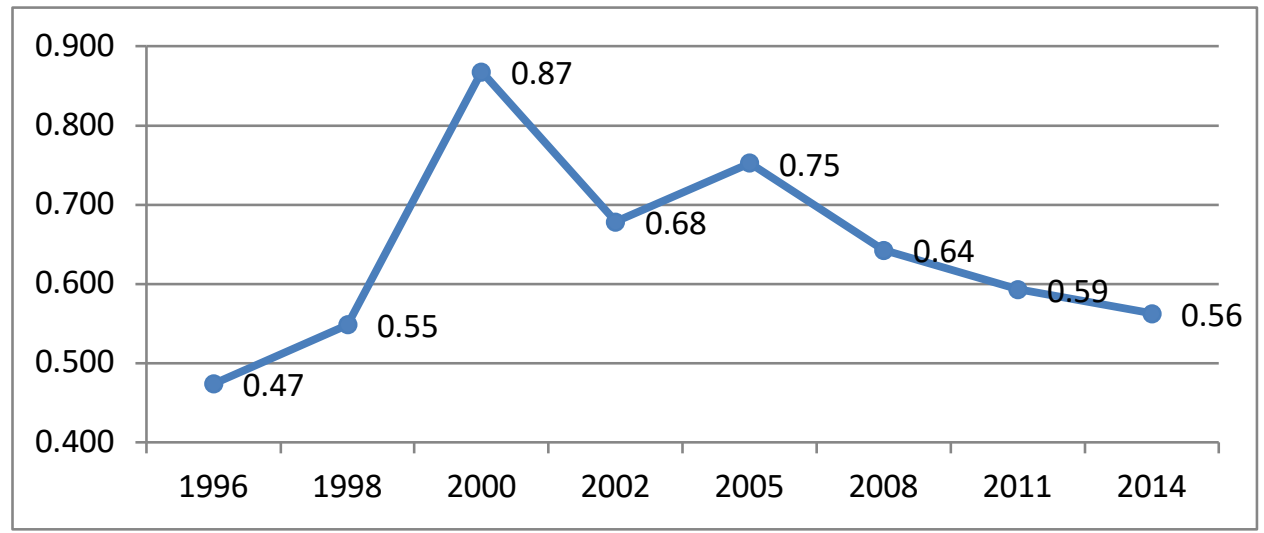

Figure 3. The Inequity of Outpatient Health Care - Theil Index

Decomposition of Outpatient Health-Care Inequity in Indonesia Province Level

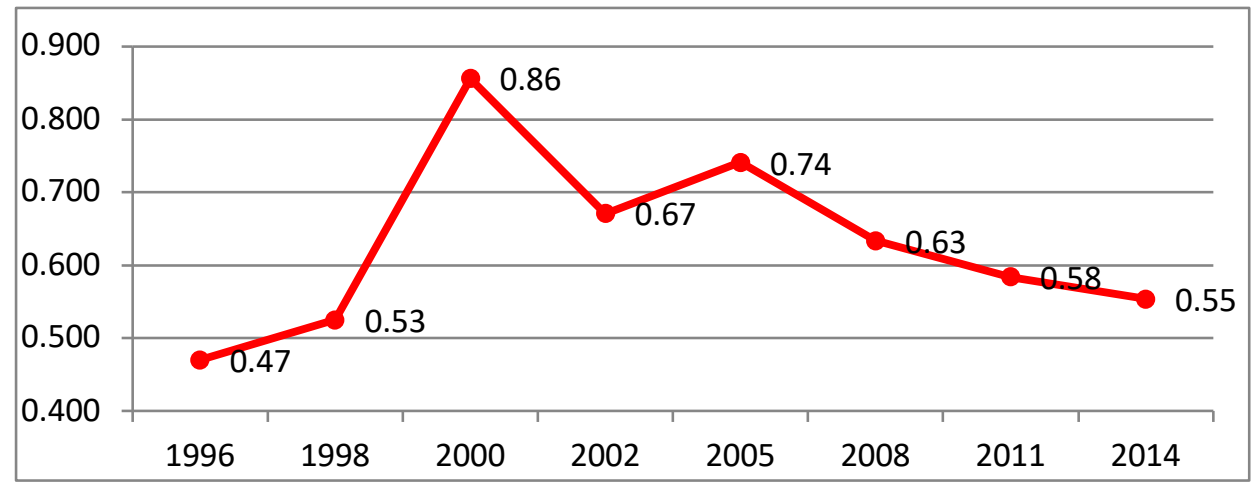

Figure 4. The Inequity of Outpatient Health Care - within Province 


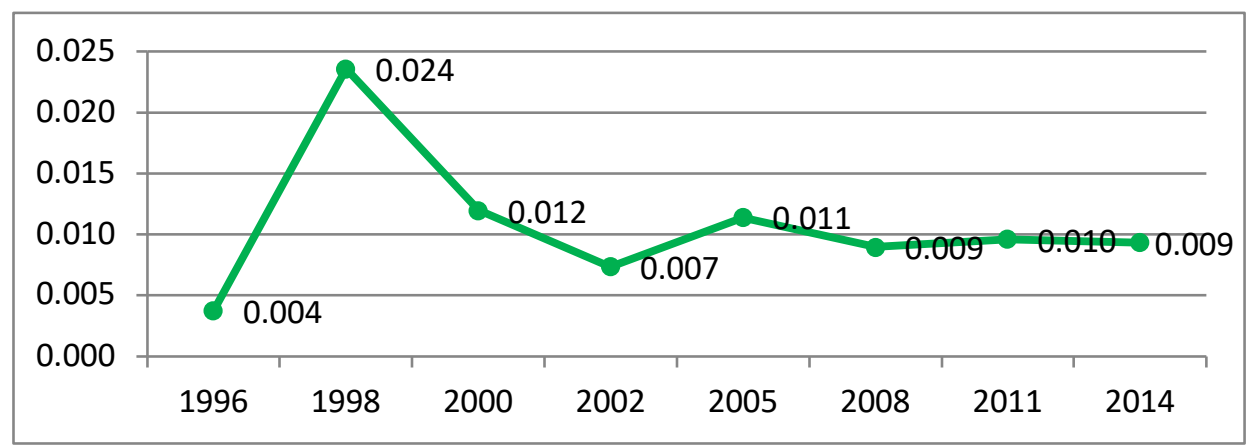

Figure 5. The inequity of Outpatient Health Care - between Province

Decomposition of Inequity Outpatient Health Care in Indonesia District/City Level

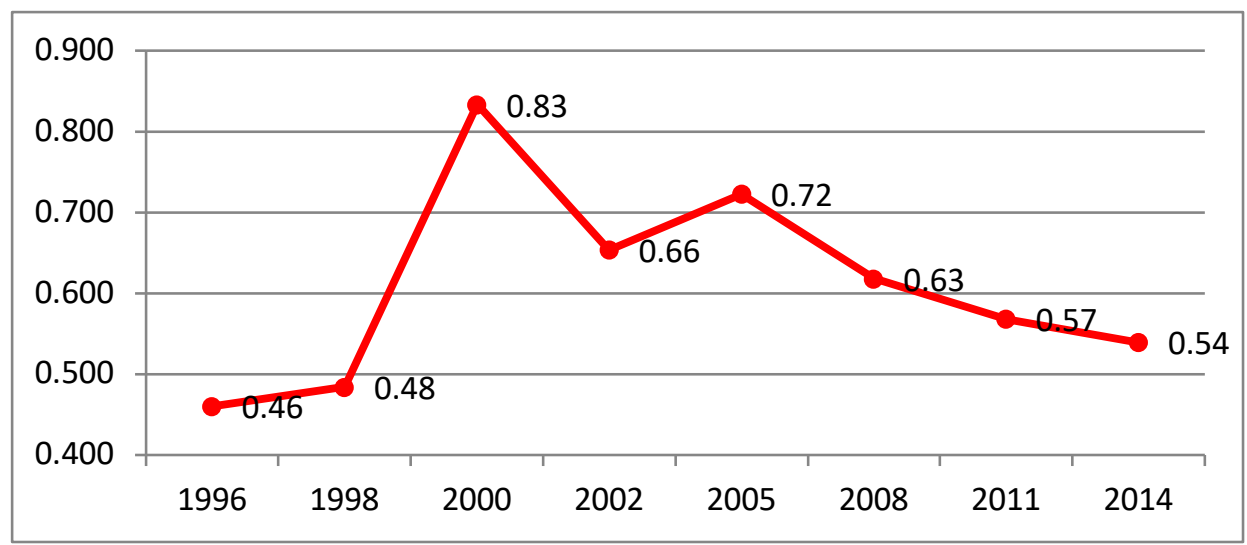

Figure 6. The Inequity of Outpatient Health Care - within District

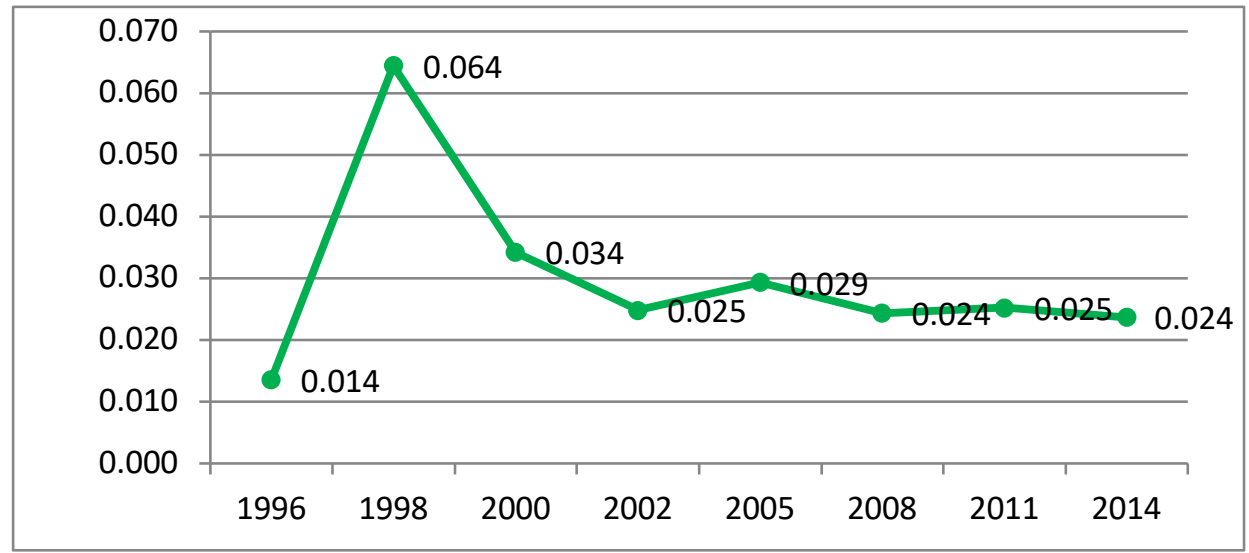

Figure 7. The inequity of Outpatient Health Care - between District 
The inequity of Inpatient Health Care in Indonesia (1996-2014)

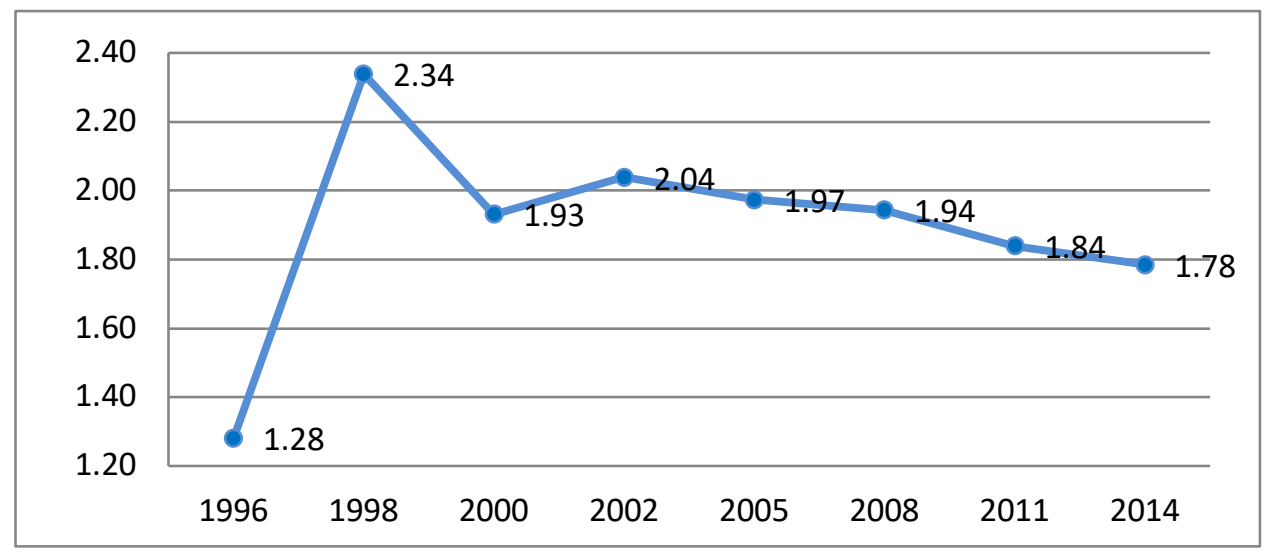

Figure 8.The inequity of Inpatient Health Care - Theil Index

Decomposition of Inequity of Inpatient Health Care in Indonesia Province Level

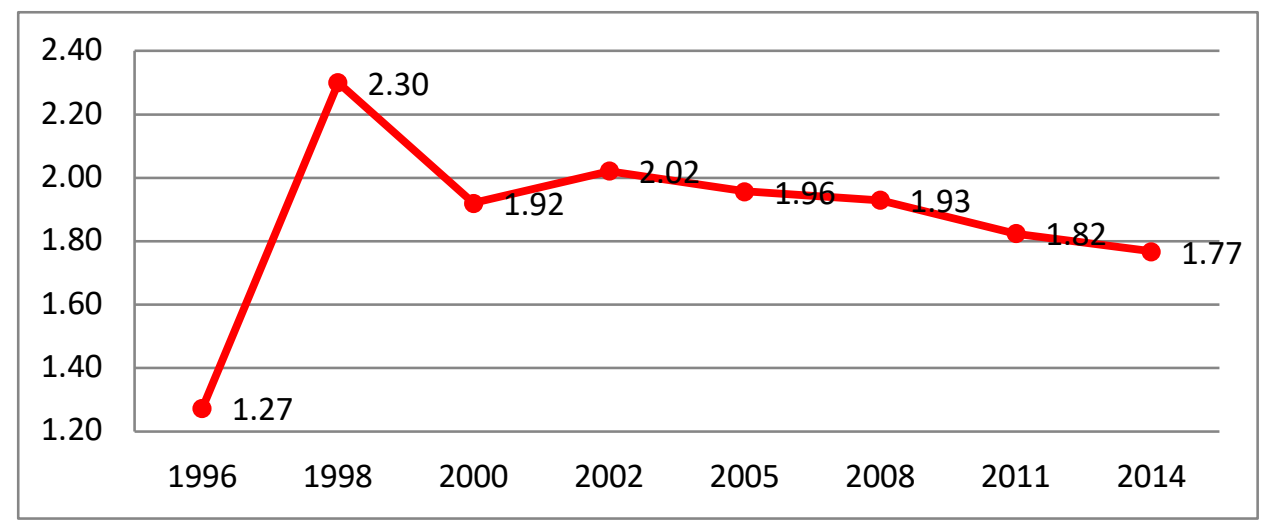

Figure 9. The Inequity of Inpatient Health Care - within Province

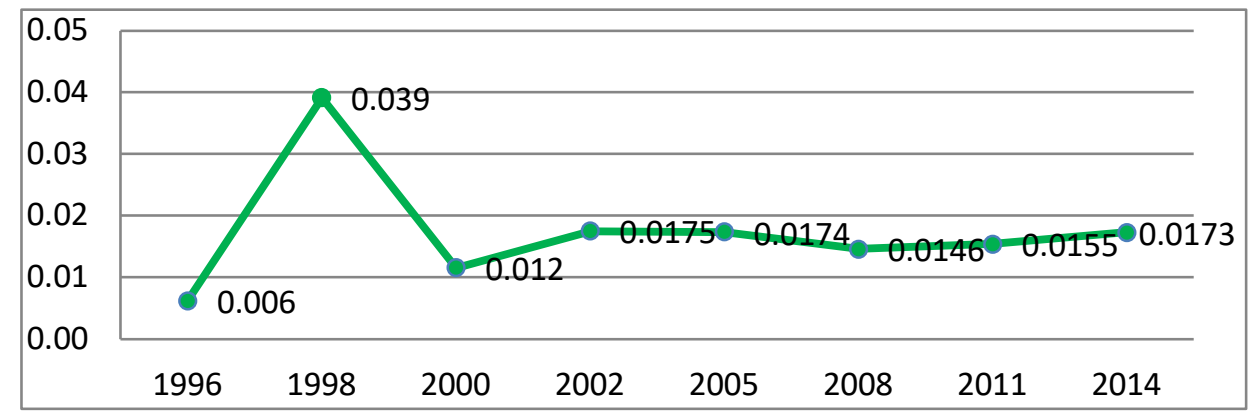

Figure 10. The Inequity of Inpatient Health Care - between Province 
Decomposition of Inequity of Inpatient Health Care in IndonesiaDistrict/City Level

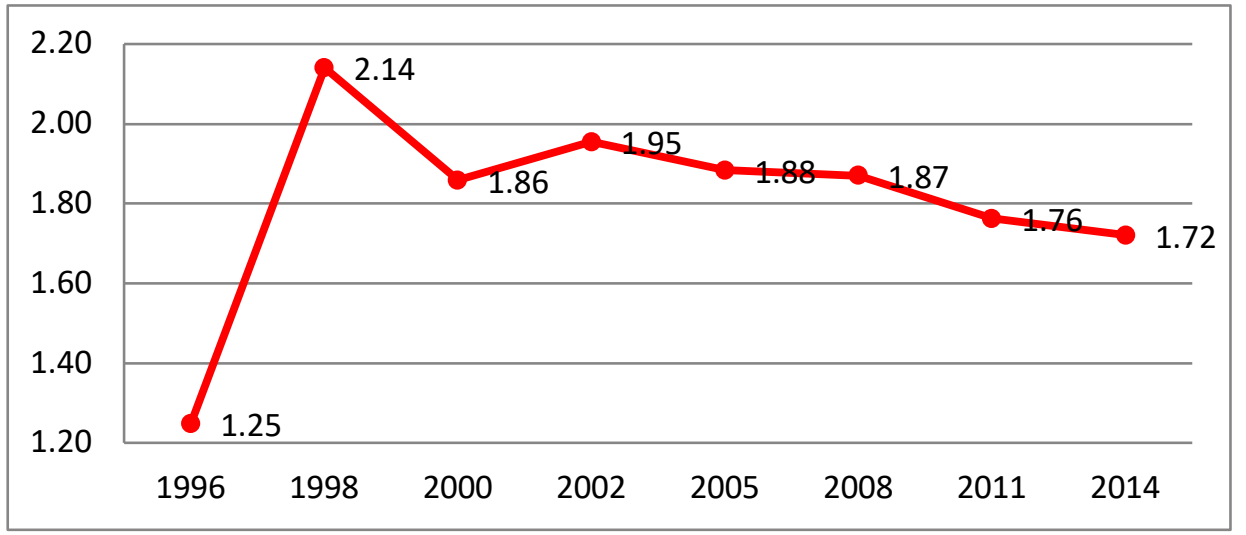

Figure 11. The Inequity of Inpatient Health Care - within District

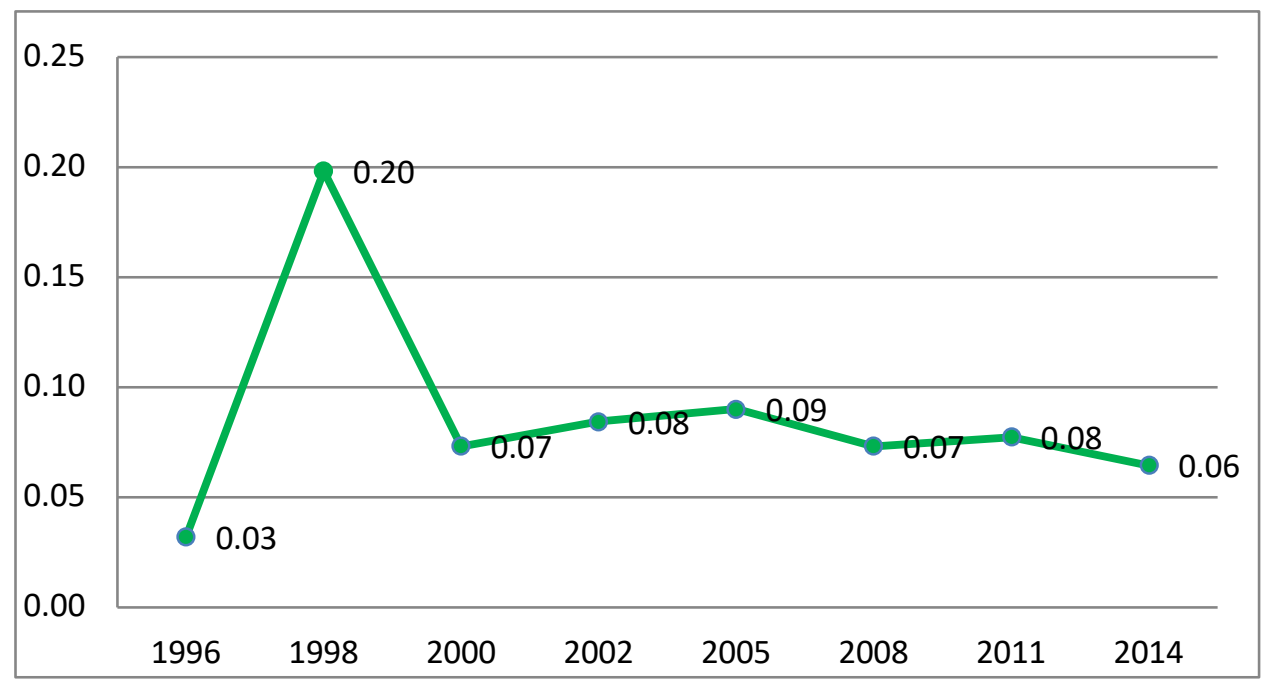

Figure 12. The Inequity of Inpatient Health Care - between District Independent sample test (t-test)

Independent sample test (t-test) also shows the difference in means of health-care inequity index for both outpatient and inpatient inequities in both province and district levels before and after decentralization are statistically different. Besides, the independent sample test also reveals the difference in means of health-care inequity in province and district levels 
between periods with and without an economic recession. The results of this independent sample test (t-test) are presented in Appendix 2.

\section{Discussion}

Between 1996 and 2014, the dynamic and pattern of average health-care utilization were different between outpatient health care and inpatient health care. The average outpatient health care in 1996 was highest in 1996. The New Order Government policy that regulated the distribution of doctors to remote areas enabled people living in remote areas to access outpatient care. In contrast, the average inpatient health care in 1996 was the lowest in 1996. In 1996, the availability of the health center that could provide inpatient health care was more limited compared to subsequent periods.

During the economic crisis in 1998, the average outpatient health care decreased substantially. During the economic crisis, the government's fiscal capacity was reduced substantially. This condition led to the decreasing availability of doctors in remote areas. However, the utilization of average inpatient health care increased. A possible explanation for this condition is the deterioration of people's health conditions during the crisis period (Saadah, Pradhan, \& Surbakti, 2000).

From 2005 to 2014, the average utilization rate of outpatient and inpatient health care tended to increase. This indicates an improvement in access to health care. The adoption of equity principle in health care is in line with the enactment of Law No. 40 of the National Social Security System of 2004 which regulates the provision of health insurance for all citizens and contributes to the improvement of access to health care through the implementation a nationwide health-care program for poor and near-poor people called ASKESKIN in 2005-2007. Later in 2008, the 
program changed to JAMKESMAS. ${ }^{2}$ JAMKESMAS program operated until 2014. Moreover, with the enactment of Law No. 32 of 2004 concerning the Local Government, the Indonesian Government together with the Indonesian Parliament agreed to expand the dimension of regional autonomy to political decentralization which mandated the direct election of the regional heads (governors/mayors/regents). These policies contribute to the improvement of the utilization rate of health care.

Concerning equity in health care, the lowest inequity in outpatient and inpatient health care occurred during the year 1996. Low inequity of outpatient health care partially can be explained with the availability of doctors in remote areas in Indonesia as the result of government policy of distributing doctors to remote areas across the country. However, low inequity of inpatient health care should be seen as underutilization of inpatient health care as the result of the limited availability of health-care centers that can provide inpatient health care.

The economic crisis contributed to the increase of both inpatient healthcare inequity. The health-care inequity between regions reached the highest point during the economic crisis compared to the period without an economic crisis.

During the second phase of decentralization (2005-2014), health-care inequity steadily decreased. Several factors contribute to the decreasing inequity of health care. Administrative decentralization was expanded to

\footnotetext{
2 The difference between JAMKESMAS and ASKESKIN is only in terms of the mechanism of program implementation.

ASKESKIN:

PT ASKES manages the health insurance funds allocated by the central government. PT ASKES verifies and pays health service bills from PPK (health service providers).

JAMKESMAS:

The government provides initial funding to health service providers (PPK) and the use of these health services is accounted for through verification that is recruited by the ministry of health as the basis for top-up health service funds. PT ASKES is only involved in membership management.

The membership coverage and health services are for the poor and almost poor individuals. This applies both to the ASKESKIN program and JAMKESMAS program.
} 
a political dimension. This policy was likely to improve the sensitivity of local government in providing health care for people in its jurisdiction. Further, a stronger nationwide health-care program also contributed to the decreased inequity of health care. This result is in line with another study in Canada (Zhong, 2010).

This study has a limitation that may require some further studies. The before and after comparison results in this study may not entirely represent the true causal relationship between decentralization of health care administration and health-care equity. The results of with and without economic crisis comparison may not also reflect the causal rapport between economic crisis and health-care equity. There are many other country-specific or region-specific or even individual-specific factors that are correlated with health-related inequity that may also alter during this period. How to completely identify the true causal relationship could become a topic of supplementary studies. Starting in 2014, Indonesia has started to run a universal health insurance program. How the impact of universal health insurance on health-care equity, especially for the spatial dimension, is an interesting question for further research topics.

\section{Conclusion}

This study provides empirical evidence regarding the source of health-care inequity from the spatial dimension which has not been addressed in previous studies using the Indonesian context. The results of this study reveal that the health-care inequities, in general, are mostly described by variations within the region (provinces and districts) in Indonesia. 
Furthermore, this study also links decentralization with health-care inequity in Indonesia. The higher degree of decentralization is associated to lower total inequity and within-province inequity in the use of outpatient health care and inpatient health care as well as related to lower between-district inequity in the use of all the two health care variables, particularly during the second phase of decentralization (20052014).

Finally, this study research also links the economic crisis with health-care equity. The results also reveal that the economic crisis in Indonesia is related to an increase in health-care inequity. 


\section{List of Abbreviations}

PT ASKES - A State-Owned Health Insurance Company that runs health benefit for active and retired government employees

PT JAMSOSTEK - A State-Owned enterprise that runs pension benefits

NSES - National Socio-Economic Survey

JAMKESMAS (Jaminan Kesehatan Masyarakat) - Social Health Insurance for the poor

ASKESKIN (Asuransi Kesehatan Masyarakat Miskin) - Health Insurance of the poor 


\section{Ethical Approval and Consent to participate}

Not Applicable

\section{Consent for publication}

Not Applicable

\section{Availability of data and materials}

The data used in the study was extracted from the The National SocioEconomic Survey (NSES) collected by the Indonesian Central Berau of Statistics (BPS). The datasets during and/or analysed during the current study available from the corresponding author on reasonable request

\section{Competing interests}

The authors declare that they have no competing interests.

\section{Funding}

This study funded by University of Indonesia through doctoral research grant.

\section{Authors' contributions}

All authors contributed to the conception and design of the study. IS performed the data analysis. IS, RAS, BRM and RQ drafted the manuscript. RAS, BRM and RQ critically revised the manuscript for important intellectual content. All authors read and approved the final manuscript.

\section{Acknowledgements}

This work was financially supported by the PITMA A research grant to the Faculty of Economic and Business University of Indonesia. The power point version of this paper was presented at the $16^{\text {th }}$ Pacific Regional Science Conference (PRSCO 2019), organized by Department of Urban and Regional Planning, Faculty of Architecture, Chulalongkorn University and Faculty of Architecture and Planning, Thammasat University, Bangkok 25- 27 July, 2019.

\section{Authors' information}

1,2,3,4 Department of Economics, Faculty of Economic and Business University of Indonesia , Depok, Indonesia 


\section{References}

Akin, J. S., Griffin, C. C., Gulkey, D. K., \& Popkin, B. M. (1986). The Demand for Primary Health Services in the Bicol Region of the Philippines. Economic Development and Cultural Changes.

Conceicao, P., \& Ferreira, P. (2000). The young person's guide to the Theil Index: Suggesting intuitive interpretation and exploring analytical application. Austin: UTIP working paper number 14 University of Texas.

Cowell, F. (2000). Measuremenotf inequality. Amsterdam: Elsevier.

Dow, W. H. (1995). Unconditional Demand for Curative Health Inputs: Does Selection on Health Status Matter in the Long Run? Working Paper, RAND and Yale University.

Fleurbay, M., \& Schokkaert, E. (2009). Unfair inequalities in health and health care. Journal of Health Economics, 73-90.

Hidayat, B., Thabrany, H., Dong, H., \& Sauerborn, R. (2004). The effect of mandatory health insurance on equity in access to outpatient care in Indonesia. Health Policy and Planning, 322-335.

Jones, A. (2000). Health Econometrics. North-Holland: Elsevier.

Maharani, D. A. (2009). Inequity in Dental Care Utilization in the Indonesian Population with a Self-Assessed Need for Dental Treatment. Tohoku J. Exp. Med, 229-239.

Maharani, D. A., \& Rahardjo, A. (2012). Is the Utilisation of dental care based on need or socioeconomic status? A study of dental care in Indonesia from 1999 to 2009. International Dental Journal, 90-94.

Mobarak, A. M., Rajkumar, A. S., \& Cropper, M. (2004). The Political Economy of Health Services Provision and Access in Brazil. Chicago: Institute of Behavioral Science (Working Paper PEC2004-0002). 
Ngrin, M., Pinilla, J., \& Abasolo, I. (2019). Horizontal equity in access to public GP services by socioeconomic group: potential bias due to a compartmentalized approach. International Journal for Equity in Health.

Nunez, A., \& Chi, C. (2013). Equity in health care utilization in Chile. International Journal for Equity in Health.

O'Donnell, O., van Doorslaer, E., Wagstaff, A., \& Lindebow, M. (2008). Analyzing Health Equity Using Household Surveyed Data: A Guide to Techniques and Their Implementation. Washington: The World Bank.

Park, J. M. (2016). Equity in the utilization of physician and inpatient hospital services: evidence from Korean health panel survey. International Journal for Equity in Health.

Phiri, J., \& Ataguba, J. E. (2014). Inequalities in public health care delivery in Zambia. International Journal for Equity in Health.

Quinonez, C., \& Grooterndorst, P. (2011). Equity in dental care among Canadian households. International Journal for Equity in Health.

Robards, F., Kang, M., Steinbeck, K., Hawke, C., Jan, S., Sanci, L., et al. (2019). Health care equity and access for marginalized young people: a longitudinal qualitative study exploring health system navigation in Australia. International Journal for Equity in Health, $18-41$.

Saadah, F., Pradhan, M., \& Surbakti, S. (2000). Health Care During Financial Crisis: What can we learn from the Indonesian National Socioeconomic Survey? Washington, DC: Human Development Network The World Bank.

Theil, H. (1967). Economics and Information Theory. Chicago: Rand McNally and Company.

Van Doorslaer, E., Koolman, X., \& Jones, A. (2004). Explaining incomerelated inequalities in health care utilization in Europe. Health Economics, 629-647. 
Wagstaff, A., \& van Doorslaer, E. (2000). Equity in Health care finance and delivery. In C. A. J, \& N. J. P, Handbook of Health Economics (pp. 1803-1862). Amsterdam: North-Holland.

Waters, H. R. (2000). Measuring Equity in Access to Healthcare. Social Science Medicine, 599-612.

Zhong, H. (2010). The impact of decentralization of health care administration on equity in health and health care in Canada. International Journal of Health Care Finance and Economics, 219-237. 


\section{Appendix.}

\section{Appendix 1: Variables}

\section{Table 1 Variables, Definitions, Measurements and Hypotheses To Estimate The Determination of Utilization of Health Care}

\begin{tabular}{|c|c|c|}
\hline Variable & Definition & Measurement \\
\hline \multicolumn{3}{|l|}{ Dependent Variable } \\
\hline Frequency Outpatient & $\begin{array}{l}\text { The arrival of respondents to } \\
\text { health care facilities for } \\
\text { outpatient/outpatient care } \\
\text { (without staying overnight) } \\
\text { which includes health care } \\
\text { facilities for hospitals, } \\
\text { health centers, doctors } \\
\text { 'practices, polyclinics and } \\
\text { health workers' practices in } \\
\text { the past month }\end{array}$ & $\begin{array}{l}\text { Frequency (how many times) of the respondent's } \\
\text { arrival to a health service center for } \\
\text { outpatient/outpatient care (without staying } \\
\text { overnight) which includes health care facilities for } \\
\text { hospitals, health centers, doctor's practices, } \\
\text { polyclinics and health workers' practices in the } \\
\text { past month }\end{array}$ \\
\hline Days Inpatient & $\begin{array}{l}\text { Number of days of } \\
\text { hospitalization in the past } \\
\text { year. }\end{array}$ & $\begin{array}{l}\text { Number of days of hospitalization by respondents } \\
\text { to health care facilities that include health facilities } \\
\text { for hospitals, health centers, doctors' practices, } \\
\text { polyclinics, practices of health workers in the past } \\
\text { year. }\end{array}$ \\
\hline \multicolumn{3}{|l|}{ Independent Variable } \\
\hline Health status & $\begin{array}{l}\text { Health condition of } \\
\text { respondents according to } \\
\text { respondents' assessment in } \\
\text { the past month*. What is } \\
\text { meant by the last month is } \\
\text { the period of the last one } \\
\text { month which ends one day } \\
\text { before the enumeration. }\end{array}$ & $\begin{array}{l}\text { Categorical variables with a value of } 1 \text { if they } \\
\text { experience health problems, but do not experience } \\
\text { activity disruption and are worth } 2 \text { if they } \\
\text { experience health problems and also experience } \\
\text { daily activities disruption. }\end{array}$ \\
\hline $\begin{array}{l}\text { Number of Health } \\
\text { disturbance }\end{array}$ & $\begin{array}{l}\text { The amount of health } \\
\text { disruption experienced by } \\
\text { respondents in the past } \\
\text { month. }\end{array}$ & $\begin{array}{l}\text { Categorical variables with a value of } 0 \text { do not } \\
\text { experience health problems, a value of } 1 \text { if you } \\
\text { experience one type of health disorder, and } 2 \text { if } \\
\text { you experience more than one health disorders. }\end{array}$ \\
\hline $\begin{array}{l}\text { Length of disturbed } \\
\text { daily activity }\end{array}$ & $\begin{array}{l}\text { The length (days) of } \\
\text { respondents who have health } \\
\text { complaints are disturbed by } \\
\text { their daily activities. }\end{array}$ & $\begin{array}{l}\text { Duration (days) of respondents who have health } \\
\text { complaints are disturbed by their daily activities in } \\
\text { the past } 1 \text { month. The number of days of disturbed } \\
\text { conditions cannot be more than } 30 \text { days because } \\
\text { the reference/reference time used is } 1 \text { month, even } \\
\text { though the health complaint has lasted more than } \\
30 \text { days. }\end{array}$ \\
\hline $\begin{array}{l}\text { Log expenditure per } \\
\text { capita (real) }\end{array}$ & Per capita expenditure & $\begin{array}{l}\text { The natural logarithm of per capita household } \\
\text { expenditure for the past month. }\end{array}$ \\
\hline
\end{tabular}




\begin{tabular}{|c|c|c|}
\hline Variable & Definition & Measurement \\
\hline Education level & $\begin{array}{l}\text { The highest level of } \\
\text { education owned by } \\
\text { respondents }\end{array}$ & $\begin{array}{l}\text { An ordinal variable that has a value of } 0-7.0= \\
\text { not/never attended school, } 1=\text { did not graduate } \\
\text { from elementary school, } 2=\text { graduated from } \\
\text { elementary school, } 3=\text { graduated from junior high } \\
\text { school, } 4=\text { graduated from high school, } 5= \\
\text { graduated from D1-D3, } 6=\text { graduated from S1, } 7= \\
\text { graduated from S2/S3 }\end{array}$ \\
\hline Age_gender_group 1 & \multirow{4}{*}{$\begin{array}{l}\text { Age and Gender Groups } \\
\text { Respondents with } \\
\text { categories of age and sex } \\
\text { were , } 1=16-56 \text { women, } 2 \\
\Rightarrow 56 \text { women, } 3=16-56 \\
\text { men, } 4=>56 \text { men. Sex age } \\
\text { group } 4 \text { (female >56 years } \\
\text { old becomes a reference). }\end{array}$} & $\begin{array}{l}\text { Dummy variable with a value of } 1 \text { if the } \\
\text { respondent is } 16-56 \text { years old and female and has a } \\
\text { value of } 0 \text { if not in category } 3\end{array}$ \\
\hline Age_gender_group2 & & $\begin{array}{l}\text { Dummy variable with a value of } 1 \text { if the } \\
\text { respondent is }>56 \text { years old and female and is } 0 \text { if } \\
\text { not in category } 4\end{array}$ \\
\hline Age_gender_group3 & & $\begin{array}{l}\text { Dummy variable with a value of } 1 \text { if the } \\
\text { respondent is } 16-56 \text { years old and male and has a } \\
\text { value of } 0 \text { if not in category } 7\end{array}$ \\
\hline Age_gender_group6 & & $\begin{array}{l}\text { Dummy variable with a value of } 1 \text { if the } \\
\text { respondent is }>56 \text { years old and male and is } 0 \text { if } \\
\text { not in category } 8\end{array}$ \\
\hline ln_expcap & Per capita expenditure & $\begin{array}{l}\text { The natural logarithm of per capita household } \\
\text { expenditure for the past month }\end{array}$ \\
\hline level of education & $\begin{array}{l}\text { The highest level of } \\
\text { education owned by } \\
\text { respondents }\end{array}$ & $\begin{array}{l}\text { An ordinal variable that has a value of } 0-7.0= \\
\text { not/never attended school, } 1=\text { did not graduate } \\
\text { from elementary school, } 2=\text { graduated from } \\
\text { elementary school, } 3=\text { graduated from junior high } \\
\text { school, } 4=\text { graduated from high school, } 5= \\
\text { graduated from D1-D3, } 6=\text { graduated from S1, } 7= \\
\text { graduated from S2 / S3 }\end{array}$ \\
\hline $\begin{array}{l}\text { Residence_- } \\
\text { domicile_city }\end{array}$ & $\begin{array}{l}\text { Location of respondent } \\
\text { residence rural/city }\end{array}$ & $\begin{array}{l}\text { Dummy variable with a value of } 1 \text { if the } \\
\text { respondent lives in an urban area and is } 0 \text { if the } \\
\text { respondent lives in a rural area. }\end{array}$ \\
\hline $\begin{array}{l}\text { Residence_domicile } \\
\text { province }\end{array}$ & $\begin{array}{l}\text { Location of the province } \\
\text { where the respondent lives. } \\
\text { The province that is the } \\
\text { reference is West Papua } \\
\text { Province }\end{array}$ & $\begin{array}{l}\text { A dummy variable with a value of } 1 \text { if the } \\
\text { respondent lives in the territory of Aceh Province } \\
\text { and } 0 \text { if he does not live in the territory of Aceh } \\
\text { Province }\end{array}$ \\
\hline
\end{tabular}




\section{Appendix 2: T-test}

1. T-test results for differences in the Theil index of outpatient and inpatient health care at the district/city and provincial level between periods of economic crisis and periods without economic crisis.

1.1. Results of statistical difference tests for within-province outpatient health-care inequity between crisis periods and non-crisis periods.

Two-sample t-test with equal variances

\begin{tabular}{|c|c|c|c|c|c|}
\hline Group & Obs & Mean & Std. Err. & Std. Dev. & [95\% Conf. Interval] \\
\hline 0 & 210 & .6635011 & .0101859 & .1476077 & 6434209.6835814. \\
\hline 1 & 33 & .5291712 & .0149839 & .086076 & $.49865 \quad .5596924$ \\
\hline Combined & 243 & .6452588 & .0094983 & .1480646 & .6265488 .6639688 \\
\hline Diff & L & 1343299 & .0264017 & & .0823224 .1863374 \\
\hline \multicolumn{4}{|c|}{$\operatorname{diff}=\operatorname{mean}(0)-\operatorname{mean}(1)$} & \multicolumn{2}{|r|}{$\mathrm{t}=5.0879$} \\
\hline \multicolumn{4}{|c|}{ Ho: diff $=0$} & \multicolumn{2}{|c|}{ degrees of freedom $=241$} \\
\hline \multicolumn{2}{|c|}{ Ha: $\operatorname{diff}<0$} & \multicolumn{2}{|c|}{ Ha: diff $!=0$} & \multicolumn{2}{|r|}{ Ha: $\operatorname{diff}>0$} \\
\hline \multicolumn{2}{|c|}{$\operatorname{Pr}(T<t)=1.0000$} & \multicolumn{2}{|c|}{$\operatorname{Pr}(|\mathrm{T}|>|\mathrm{t}|)=0.0000$} & \multicolumn{2}{|r|}{$\operatorname{Pr}(T>t)=0.0000$} \\
\hline
\end{tabular}

\section{Interpretations and conclusions:}

The calculated $t$ value is 5.0879 with a $P$-value of $\operatorname{Pr}(|\mathrm{T}|>|\mathrm{t}|)=0.0000$ in the degree of freedom (DF) 241. DF is the total number of samples in both groups minus $2(\mathrm{~N}-2=241)$. Because the value of 0.0000 is less than the critical limit of 0.05 , the hypothesis decision is to accept $\mathrm{H} 1$ or, when there is a significant difference in mean between the two outpatient health care, Theil indexes at the provincial level between periods of economic crisis and periods without economic crisis.

1.2. Results of statistical difference tests for within-province inpatient healthcare inequity between crisis periods and non-crisis periods

Two-sample t-test with equal variances

\begin{tabular}{|c|c|c|c|c|}
\hline Group & Obs & Mean & Std. Dev. & [95\% Conf. Interval] \\
\hline 0 & 208 & 1.817904 & .3266658 & 1.7732491 .862558 \\
\hline 1 & 33 & 2.126518 & .6195878 & $1.906822 \quad 2.346214$ \\
\hline combined & 241 & 1.860162 & .3930976 & 1.810281 \\
\hline Diff & 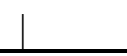 & 3086143 & .0710613 & $-.4486007 \quad-.1686279$ \\
\hline \multicolumn{3}{|c|}{$\operatorname{diff}=\operatorname{mean}(0)-\operatorname{mean}(1)$} & \multicolumn{2}{|r|}{$\mathrm{t}=-4.3429$} \\
\hline \multicolumn{3}{|c|}{ Ho: $\operatorname{diff}=0$} & \multicolumn{2}{|c|}{ degrees of freedom $=239$} \\
\hline \multicolumn{3}{|c|}{ Ha: $\operatorname{diff}<0$} & \multicolumn{2}{|c|}{$0 \quad$ Ha: $\operatorname{diff}>0$} \\
\hline \multicolumn{3}{|c|}{$\operatorname{Pr}(\mathrm{T}<\mathrm{t})=0.0000$} & $\operatorname{Pr}(|\mathrm{T}|>|\mathrm{t}|)=0.0000$ & $\operatorname{Pr}(\mathrm{T}>\mathrm{t})=1.0000$ \\
\hline
\end{tabular}

\section{Interpretations and conclusions:}

The calculated $t$ value is -43429 with a $\mathrm{P}$-value of $\operatorname{Pr}(|\mathrm{T}| \mathrm{P}|\mathrm{t}|)=0.0000$ in degree of freedom (DF) 239. DF here is the total number of samples in both groups minus $2(\mathrm{~N}-2=239)$. Because the value of 0.0000 is less than the critical limit of 0.05 , the hypothesis decision is to accept $\mathrm{H} 1$ or, when there is a 
significant difference in mean between the two inpatient health care, Theil Indexes at the provincial level between periods of economic crisis and periods without economic crisis.

1.3. Results of statistical difference tests for within-district/city outpatient health-care inequity between crisis periods and non-crisis periods

Two-sample t-test with equal variances

\begin{tabular}{c|ccccc}
\hline Group & Obs & Mean & Std. Err. & Std. Dev. [95\% Conf. nterval] \\
\hline 0 & 2663 & .6349819 & .0033471 & .1727254 & .6284187 .6415451 \\
1 & 285 & .4869201 & .0093856 & .1584465 & .468446 .5053942 \\
\hline Combined & 2948 & .6206679 & .0032576 & .1768709 & .6142806 .6270553 \\
\hline Diff & .1480619 & .0106824 & .1271162 .1690076 \\
\hline diff $=$ mean $(0)-$ mean $(1)$ & \multicolumn{3}{c}{ degrees of freedom $=13.8604$} \\
Ho: diff $=0$ & & Ha: diff $!=0$ & Ha: diff $>0$ \\
Ha: diff $<0$ & & Pr $(\mathrm{T}>\mathrm{t})=0.0000$
\end{tabular}

\section{Interpretations and conclusions:}

The calculated $t$ value is 13.8604 with a $\mathrm{P}$-value of $\operatorname{Pr}(|\mathrm{T}|>|\mathrm{t}|)=0.0000$ in the degree of freedom (DF) 2946. DF here is the total number of samples in both groups minus $2(\mathrm{~N}-2=2946)$. Because the value of 0.0000 is less than the critical limit of 0.05 , the hypothesis decision is to accept $\mathrm{H} 1$ or, when there is a significant difference in mean between the two inpatient health care, Theil Indexes at the district/city level between periods of economic crisis and periods without economic crisis.

1.4. Results of statistical difference tests for within-district/city inpatient health-care inequity between crisis periods and non-crisis periods

Two-sample t-test with equal variances

\begin{tabular}{|c|c|c|c|c|}
\hline Group & Obs & Mean & Std. Err. & Std. Dev.[95\% Conf. Interval] \\
\hline 0 & 2663 & 1.635562 & .009829 & $\begin{array}{lll}.5072189 & 1.616288 & 1.654835\end{array}$ \\
\hline 1 & 285 & 1.66878 & .0448476 & 1.5805041 .757056 \\
\hline Combined & 2948 & 1.638773 & .0098793 & $\begin{array}{lll}.536403 & 1.619402 & 1.658144 \\
\end{array}$ \\
\hline Diff & & -.0332182 & .0334309 & -.0987685 .0323321 \\
\hline \multicolumn{4}{|c|}{$\operatorname{diff}=\operatorname{mean}(0)-\operatorname{mean}(1)$} & $t=-0.9936$ \\
\hline \multicolumn{4}{|c|}{ Ho: $\operatorname{diff}=0$} & degrees of freedom $=2946$ \\
\hline \multicolumn{3}{|c|}{ Ha: $\operatorname{diff}<0$} & Ha: diff $!=0$ & Ha: $\operatorname{diff}>0$ \\
\hline \multicolumn{3}{|c|}{$\operatorname{Pr}(T<t)=0.1602$} & $|>| t \mid)=0.3205$ & $\operatorname{Pr}(\mathrm{T}>\mathrm{t})=0.8398$ \\
\hline
\end{tabular}

\section{Interpretations and conclusions:}

The calculated $t$ value is $-0,9936$ with a $\mathrm{P}$-value of $\operatorname{Pr}(|\mathrm{T}|>|\mathrm{t}|)=0.3205$ in degree of freedom (DF) 2948. DF here is the total number of samples in both groups minus $2(\mathrm{~N}-2=2948)$. Because the value of 0.3205 is greater than the critical limit of 0.05 , the hypothesis decision is to accept $\mathrm{H} 1$ or, when there is no difference in mean between the two inpatient health care, Theil Indexes at the 
district/city level between periods of economic crisis and periods without economic crisis.

2. The t-test results for differences in the Thiel index of outpatient and inpatient health care at the district/city and provincial level between periods of before and after decentralization

2.1. Results of statistical difference tests for within province outpatient health-care inequity between before and after decentralization periods

Two-sample t-test with equal variances

\begin{tabular}{|c|c|c|c|c|}
\hline Group & Obs & Mean & Std. Err. & Std. Dev. [95\% Conf. Interval] \\
\hline 0 & 58 & .5098983 & .0100829 & $\begin{array}{lll}.0767894 & .4897075 & .530089\end{array}$ \\
\hline 1 & 185 & .6876962 & .0102458 & $.1393582 \quad 6674818$ \\
\hline combined & 243 & .6452588 & .0094983 & .1480646 .6265488 \\
\hline diff & & -.1777979 & .0191671 & $-.2155543-.1400415$ \\
\hline \multicolumn{4}{|c|}{$\operatorname{diff}=\operatorname{mean}(0)-\operatorname{mean}(1)$} & $t=-9.2762$ \\
\hline \multicolumn{4}{|c|}{ Ho: $\operatorname{diff}=0$} & degrees of freedom $=241$ \\
\hline \multicolumn{2}{|c|}{ Ha: $\operatorname{diff}<0$} & \multicolumn{2}{|c|}{ Ha: diff $!=0$} & Ha: $\operatorname{diff}>0$ \\
\hline \multicolumn{2}{|c|}{$\operatorname{Pr}(T<t)=0.0000$} & \multicolumn{2}{|c|}{$\operatorname{Pr}(|\mathrm{T}|>|\mathrm{t}|)=0.0000$} & $\operatorname{Pr}(\mathrm{T}>\mathrm{t})=1.0000$ \\
\hline
\end{tabular}

Interpretations and conclusions:

The calculated $t$ value is $-9,2762$ with a $\mathrm{P}$-value of $\operatorname{Pr}(|\mathrm{T}|>|\mathrm{t}|)=0.0000$ in degree of freedom (DF) 241. DF here is the total number of samples in both groups minus $2(\mathrm{~N}-2=241)$. Because the value of 0.000 is less than the critical limit of 0.05 , the hypothesis decision is to accept $\mathrm{H} 1$ or, when there is a significant difference in mean between the two outpatient health care, Theil indexes at the province level between periods of before and after decentralization.

2.2. Results of statistical difference tests for within-province inpatient healthcare inequity between before and after decentralization periods

Two-sample t-test with equal variances

\begin{tabular}{c|cccccc}
\hline Group & Obs & Mean & Std. Err. & Std. Dev. & [95\% Conf. Interval] \\
\hline 0 & 58 & 1.763832 & .0830755 & .6326843 & 1.597476 & 1.930188 \\
1 & 183 & 1.890693 & .0201782 & .2729659 & 1.85088 & 1.930506 \\
Combined $\mid$ & 241 & 1.860162 & .0253216 & .3930976 & 1.810281 & 1.910043 \\
\hline diff & & -.126861 & .0587876 & & -.2426691 & -.011053 \\
\hline diff $=$ mean $(0)$ - mean(1) & & & degrees of freedom $=$ & 239 \\
Ho: diff $=0$ \\
$\begin{array}{c}\text { Ha: diff }<0 \\
\text { Pr }(\mathrm{T}<\mathrm{t})=0.0160\end{array}$
\end{tabular}

\section{Interpretations and conclusions:}

The calculated $t$ value is $-2,5180$ with a $P$-value of $\operatorname{Pr}(|\mathrm{T}|>|\mathrm{t}|)=0.0319$ in degree of freedom (DF) 239. DF here is the total number of samples in both groups minus $2(\mathrm{~N}-2=239)$. Because the value of 0.0319 is less than the critical limit of 0.05 , the hypothesis decision is to accept $\mathrm{H} 1$ or, when there is a 
significant difference in mean between the two inpatient health care, Theil indexes at the province level between periods of before and after decentralization.

2.3. Results of statistical difference tests for within-district/city outpatient health-care inequity between before and after decentralization periods Two-sample t-test with equal variances

\begin{tabular}{|c|c|c|c|c|}
\hline Group & Obs & Mean & Std. Dev. & [95\% Conf. Interval] \\
\hline 0 & 571 & .4757319 & .0054528 & .4650218 \\
\hline 1 & 2377 & .6554843 & .0034607 & .6486981 \\
\hline Combined & 2948 & .6206679 & .0032576 & $\begin{array}{ll}6142806 & .6270553 \\
\end{array}$ \\
\hline Diff & & -.1797525 & .00755 & $-.1945563-.1649486$ \\
\hline \multicolumn{4}{|c|}{$\operatorname{diff}=\operatorname{mean}(0)-\operatorname{mean}(1)$} & $\mathrm{t}=-23.8081$ \\
\hline \multicolumn{5}{|c|}{ Ho: $\operatorname{diff}=0$} \\
\hline \multicolumn{2}{|c|}{ Ha: $\operatorname{diff}<0$} & \multicolumn{2}{|r|}{ Ha: diff $!=0$} & Ha: $\operatorname{diff}>0$ \\
\hline \multicolumn{2}{|c|}{$\operatorname{Pr}(T<t)=0.0000$} & \multicolumn{2}{|c|}{$\operatorname{Pr}(|\mathrm{T}|>|\mathrm{t}|)=0.0000$} & $\operatorname{Pr}(\mathrm{T}>\mathrm{t})=1.0000$ \\
\hline
\end{tabular}

\section{Interpretations and conclusions:}

The calculated $t$ value is -23.8081 with a $\mathrm{P}$-value of $\operatorname{Pr}(|\mathrm{T}|>|\mathrm{t}|)=0.0000$ in degree of freedom (DF) 2946. DF here is the total number of samples in both groups minus $2(\mathrm{~N}-2=2946)$. Because the value of 0.0000 is less than the critical limit of 0.05 , the hypothesis decision is to accept $\mathrm{H} 1$ or, when there is a significant difference in mean between the two outpatient health care, Theil indexes at the district/city level between periods of before and after decentralization

2.4. Results of statistical difference tests for within-district/city inpatient health-care inequity between before and after decentralization periods

Two-sample t-test with equal variances

\begin{tabular}{c|cccccc}
\hline Group & Obs & Mean & Std. Err. & Std. Dev. & [95\% Conf. Interval] \\
\hline 0 & 571 & 1.433254 & .0258777 & .6183639 & 1.382426 & 1.484081 \\
1 & 2377 & 1.688143 & .0103077 & .5025483 & 1.66793 & 1.708356 \\
\hline Combined $\mid$ & 2948 & 1.638773 & .0098793 & .536403 & 1.619402 & 1.658144 \\
\hline Diff & -.2548891 & .0245583 & & -.3030422 & -.206736 \\
\hline diff $=$ mean $(0)-$ mean $(1)$ & & & degrees of freedom $=-10.3790$ & 2946 \\
Ho: diff $=0$ & & Ha: diff $!=0$ & Ha: diff $>0$ \\
Ha: diff $<0$ & & $\operatorname{Pr}(|\mathrm{T}|>|\mathrm{t}|)=0.0000$ & $\operatorname{Pr}(\mathrm{T}>\mathrm{t})=1.0000$
\end{tabular}

\section{Interpretations and conclusions:}

The calculated $t$ value is -10.3790 with a $\mathrm{P}$-value of $\operatorname{Pr}(|\mathrm{T}|>|\mathrm{t}|)=0.0000$ in degree of freedom (DF) 2946. DF here is the total number of samples in both groups minus $2(\mathrm{~N}-2=2946)$. Because the value of 0.0000 is less than the critical limit of 0.05 , the hypothesis decision is to accept $\mathrm{H} 1$ or, when there is a significant difference in mean between the two inpatient health care, Theil 
indexes at the district/city level between periods of before and after decentralization

i This study limits the study sample to adults who experience health problems. Sample limitations are prevalent in studies of curative health-care inequity. A more detailed explanation on this matter can refer to (Akin, Griffin, Gulkey, \& Popkin, 1986; Dow, 1995; Mobarak, Rajkumar, \& Cropper, 2004; Waters, 2000; Hidayat, Thabrany, Dong, \& Sauerborn, 2004; Maharani \& Rahardjo, 2012; Maharani D. A., 2009) 
Figures

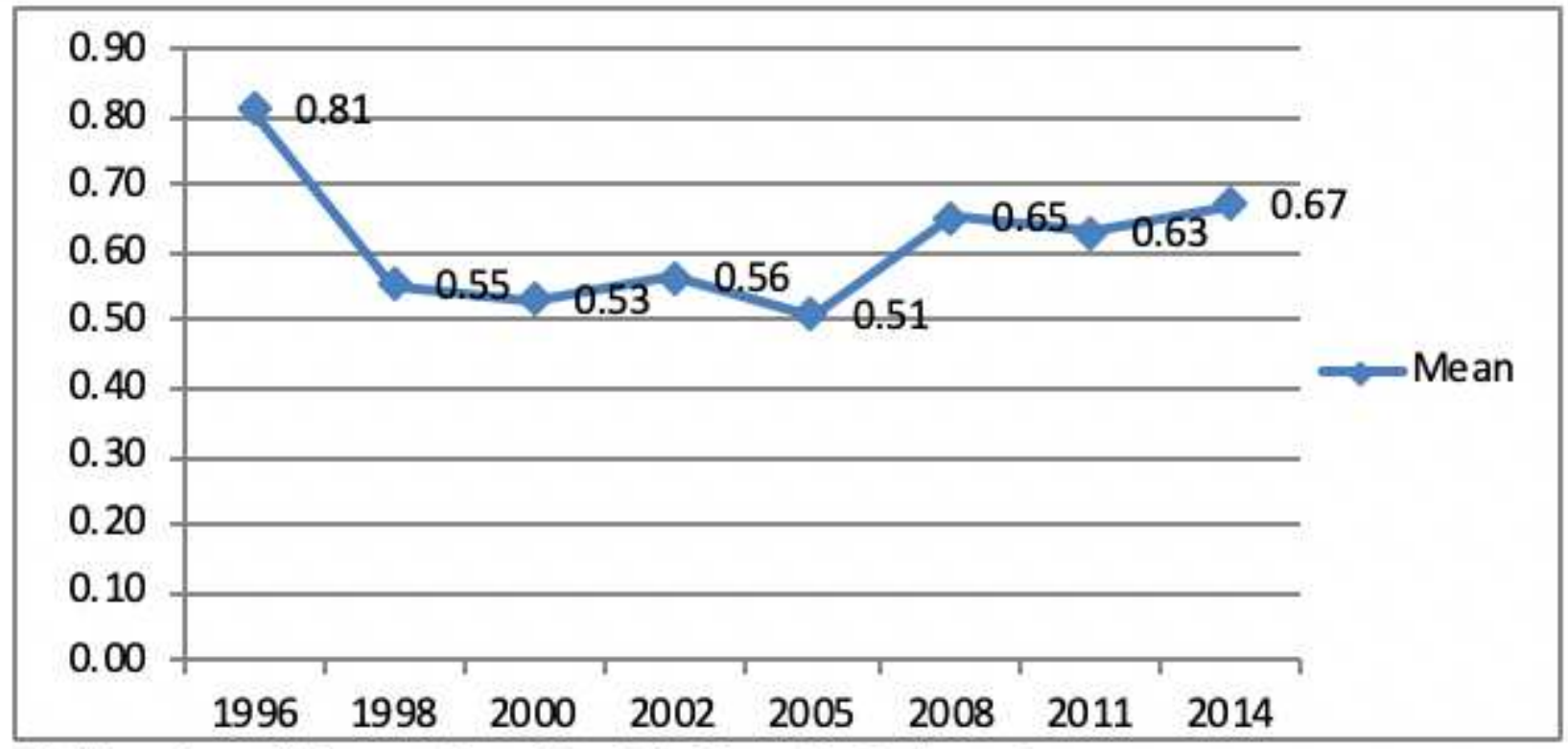

Utilization of Outpatient Health Care in Indonesia

Figure 1

Average Utilization of Outpatient Health Care (Number of Visits) Per Individual

Utilization of Inpatient Health Care in Indonesia

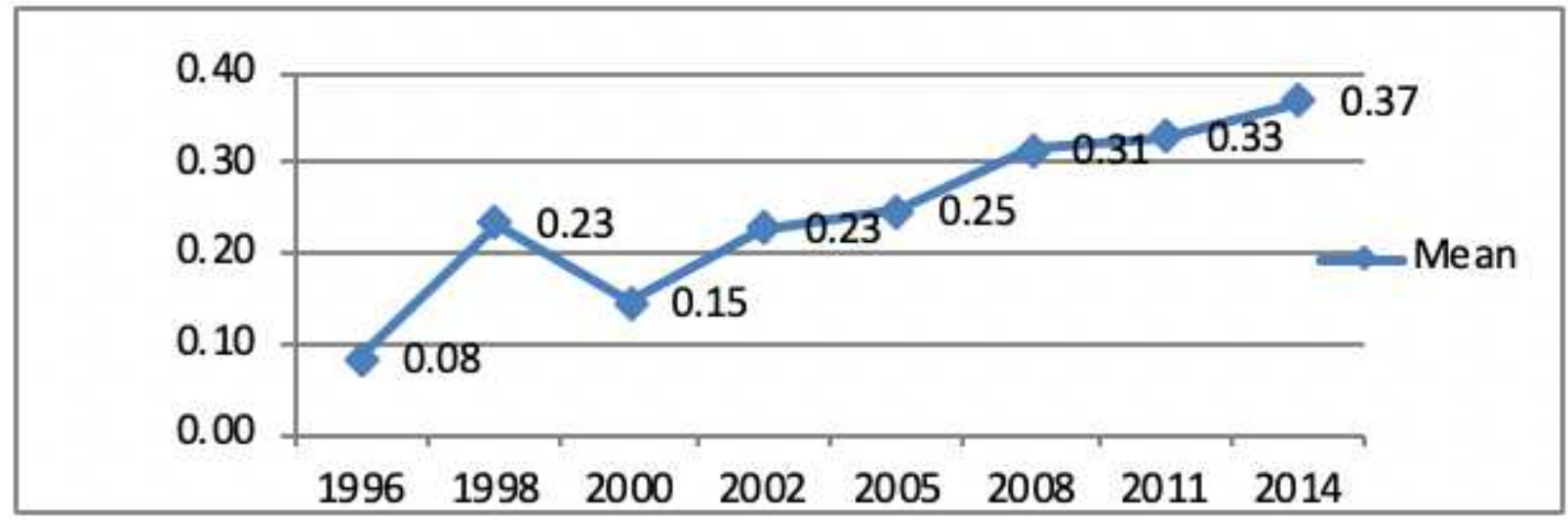

Figure 2

Average Utilization of Inpatient Health Care (Days Spent) Per Individual 
The Inequity of Outpatient Health Care in Indonesia (1996-2014)

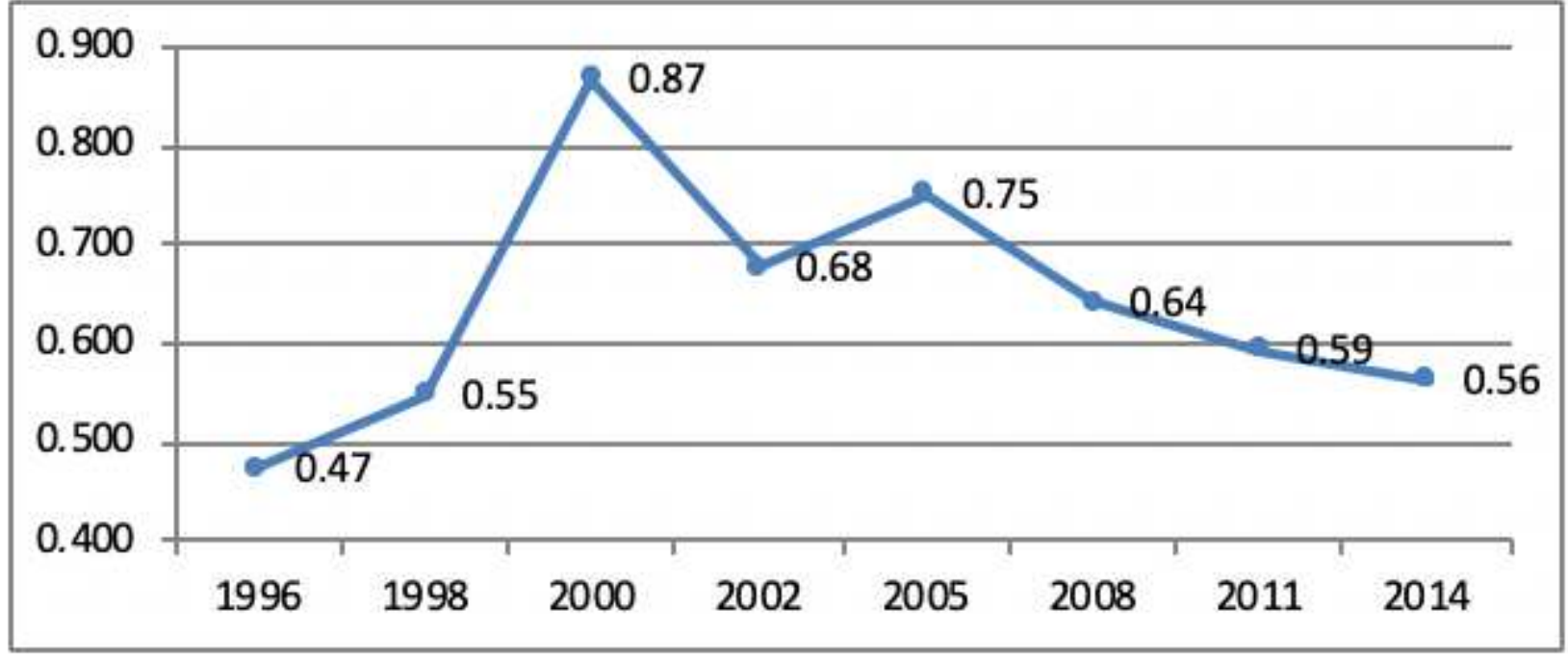

Figure 3

The Inequity of Outpatient Health Care - Theil Index

Decomposition of Outpatient Health-Care Inequity in Indonesia Province Level

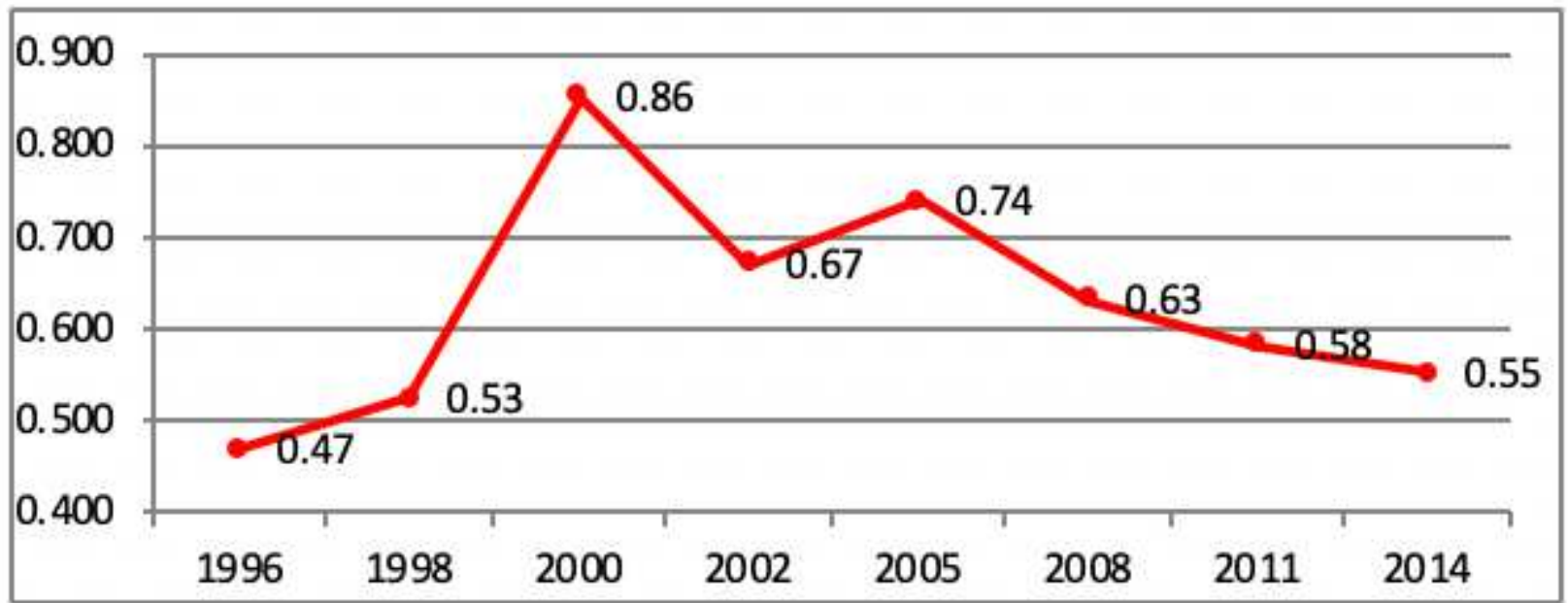

Figure 4

The Inequity of Outpatient Health Care - within Province 


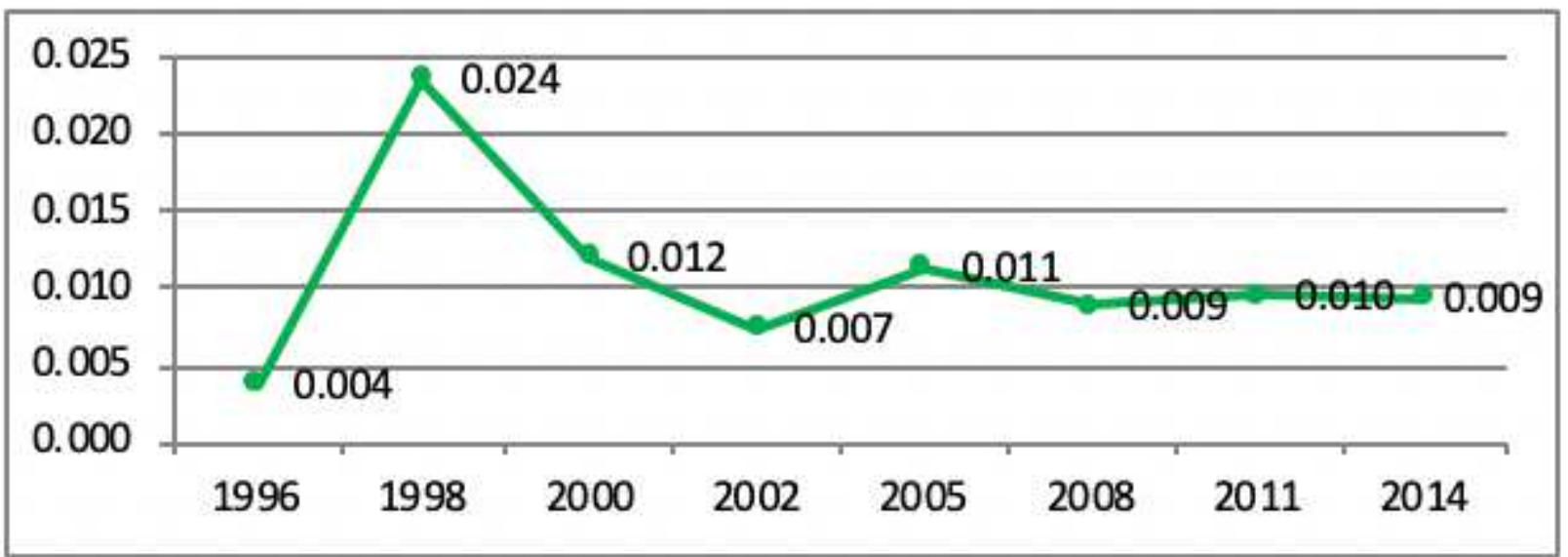

Figure 5

The inequity of Outpatient Health Care - between Province

Decomposition of Inequity Outpatient Health Care in Indonesia District/City Level

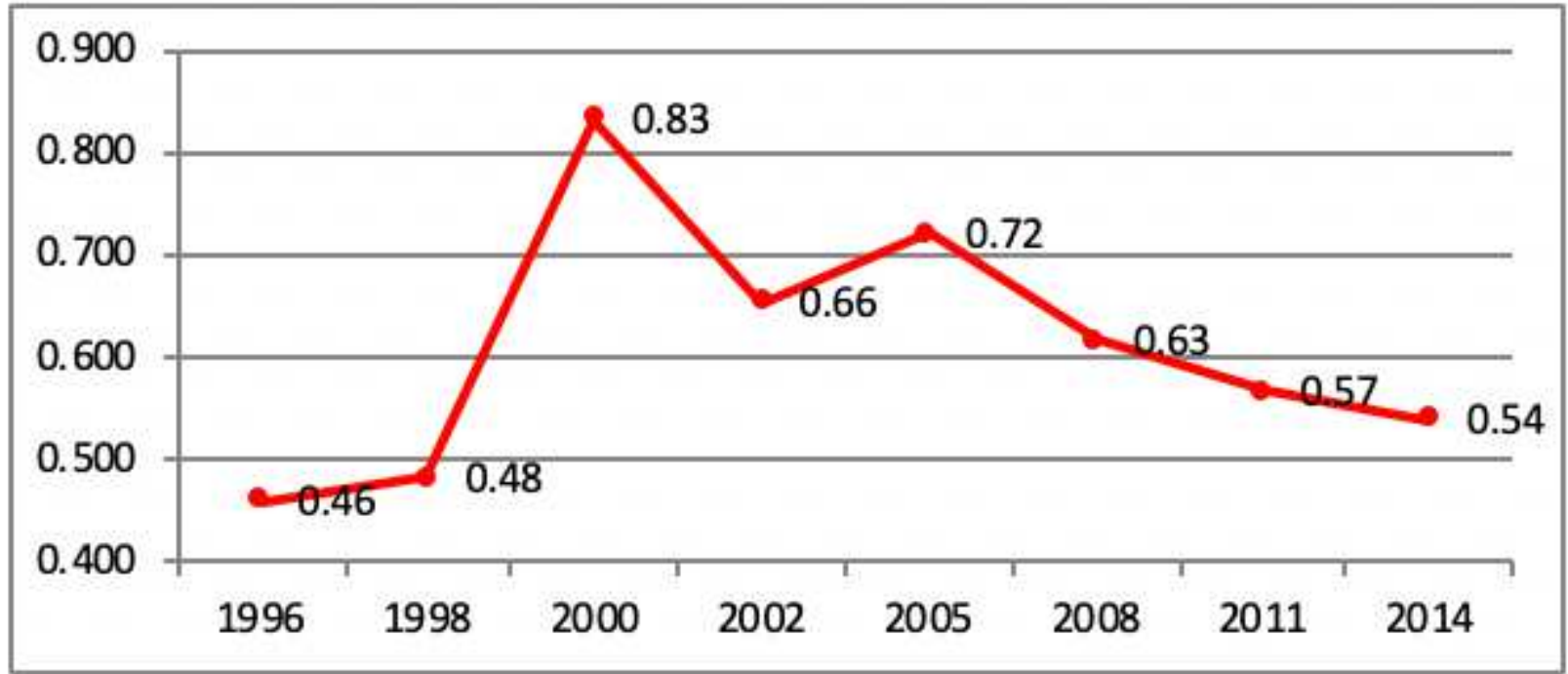

Figure 6

The Inequity of Outpatient Health Care - within District 


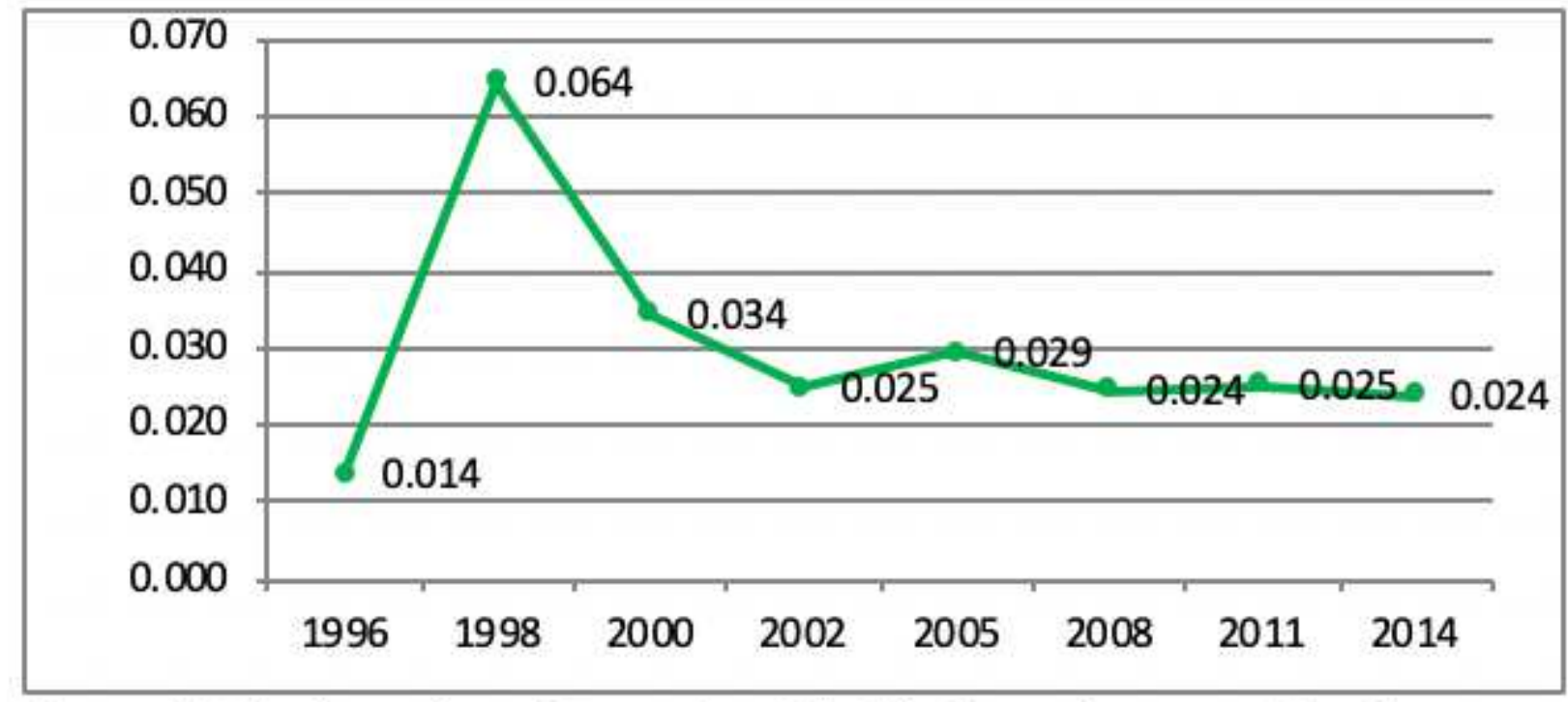

Figure 7

The inequity of Outpatient Health Care - between District

The inequity of Inpatient Health Care in Indonesia (1996-2014)

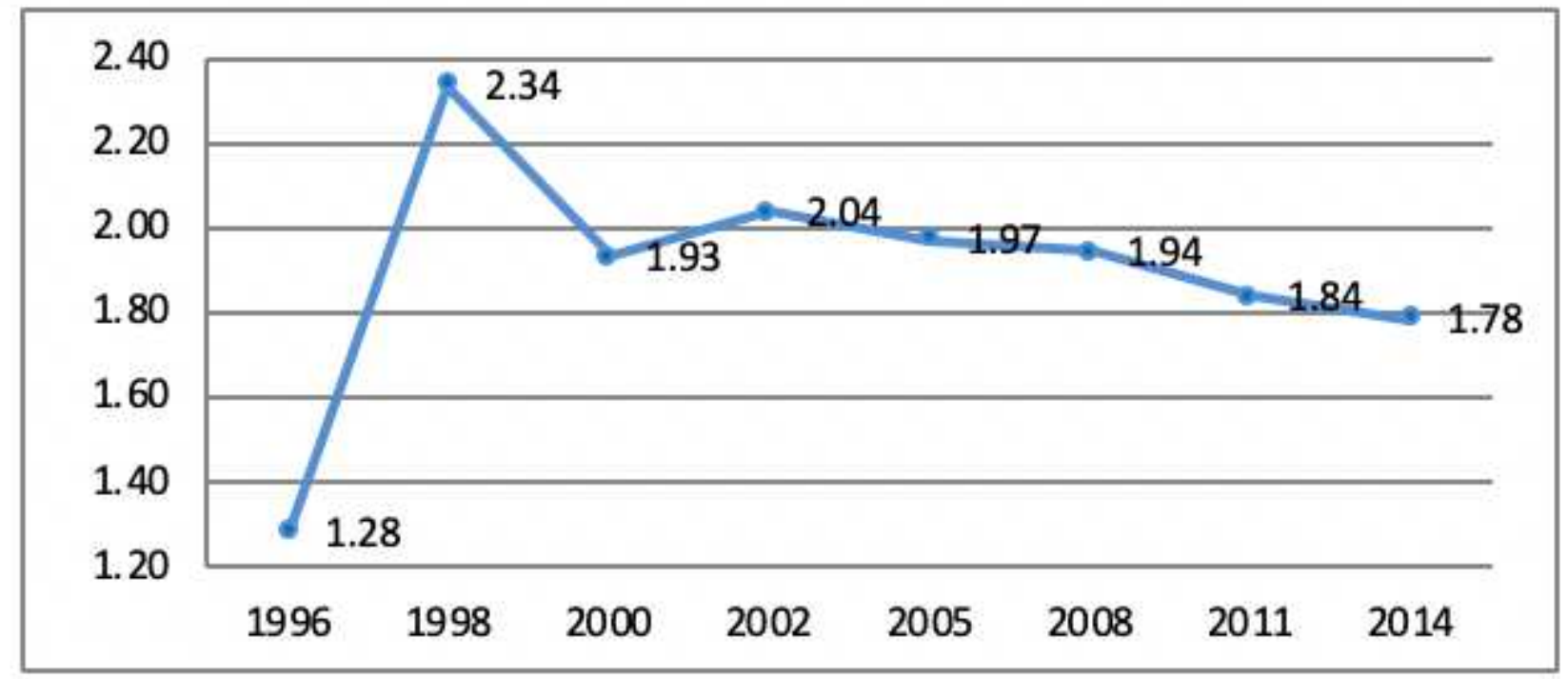

Figure 8

The inequity of Inpatient Health Care - Theil Index 
Decomposition of Inequity of Inpatient Health Care in Indonesia Province Level

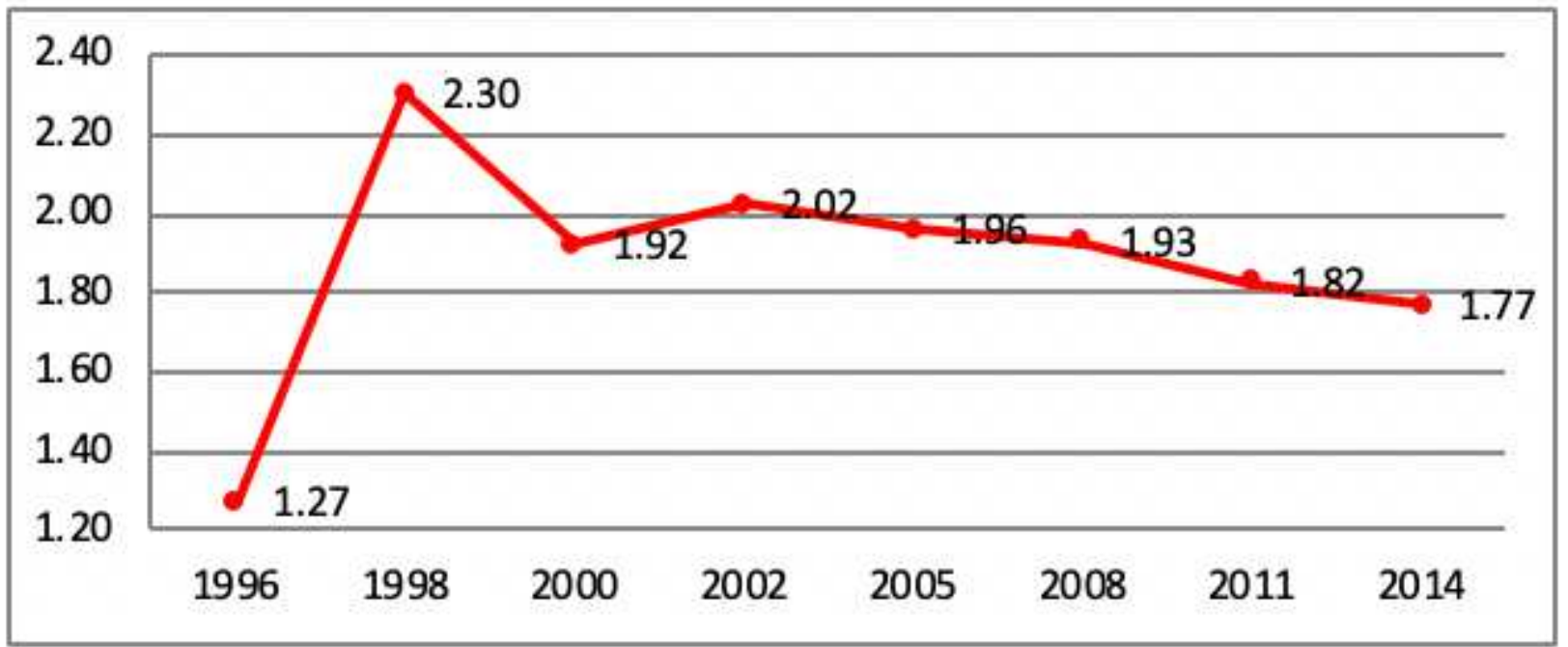

Figure 9

The Inequity of Inpatient Health Care - within Province

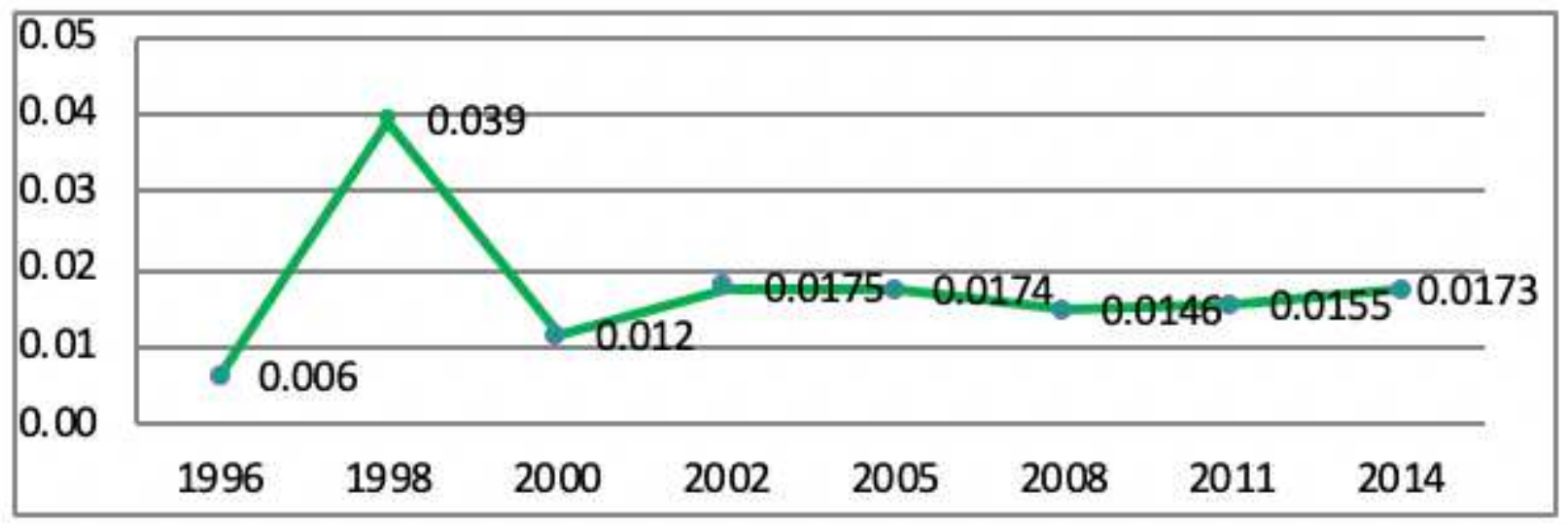

Figure 10

The Inequity of Inpatient Health Care - between Province 
Decomposition of Inequity of Inpatient Health Care in Indonesia. District/City Level

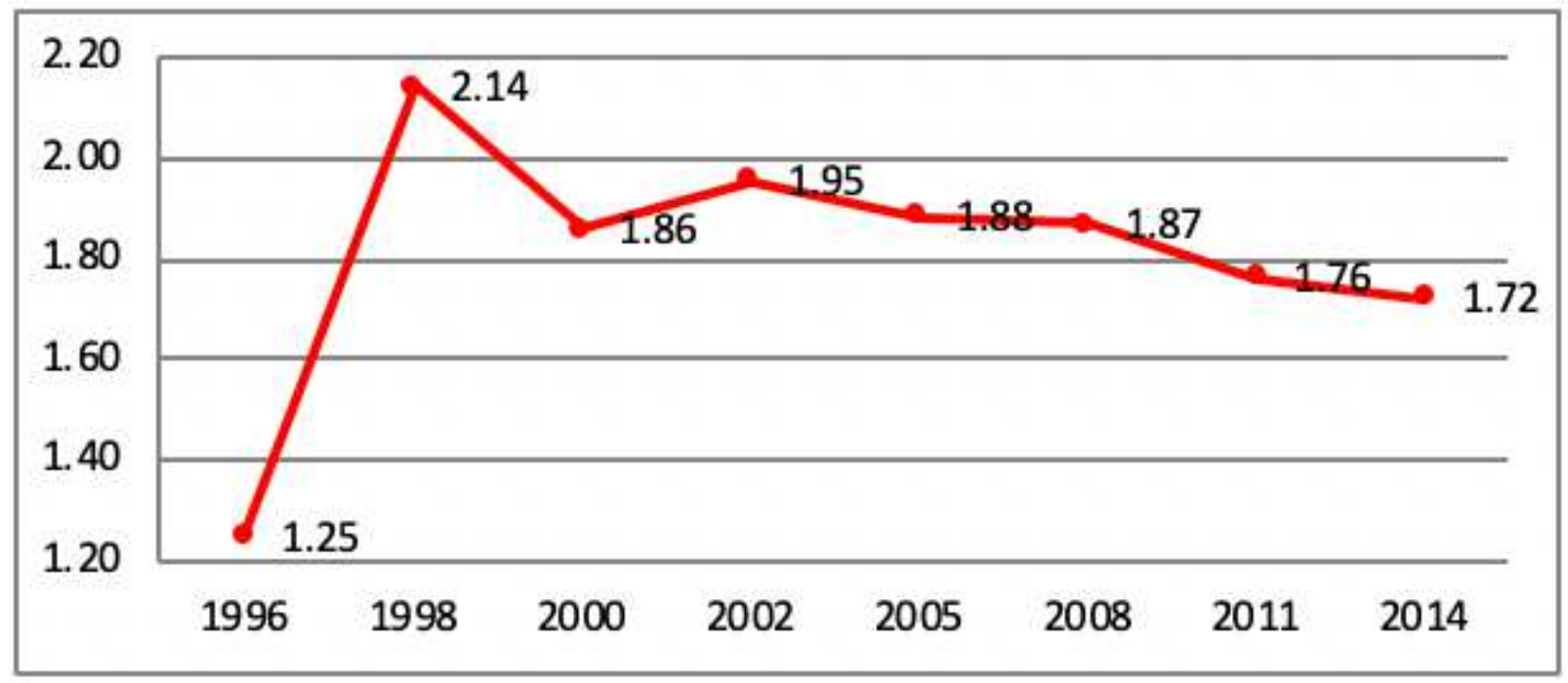

Figure 11

The Inequity of Inpatient Health Care - within District

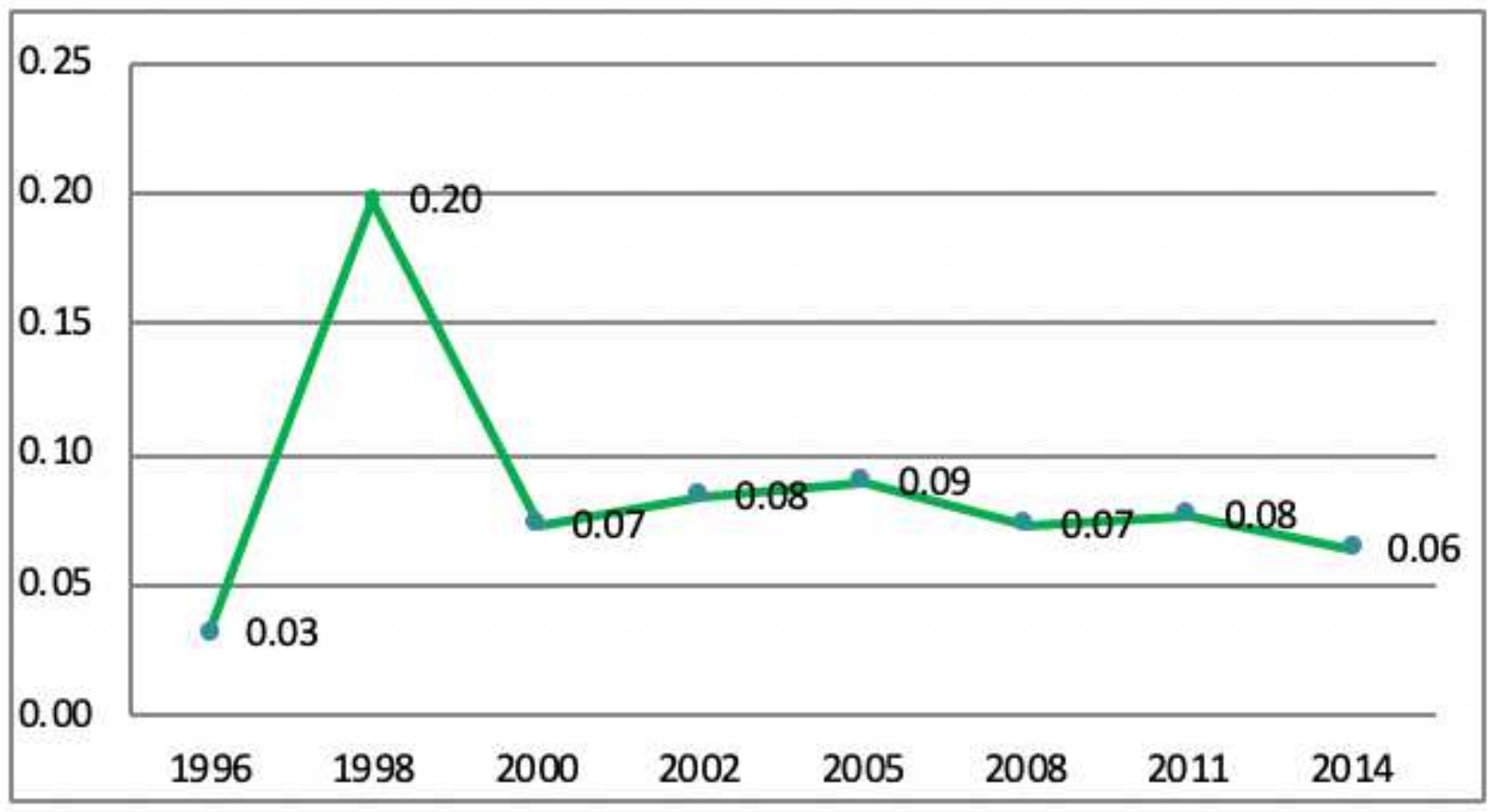

Figure 12

The Inequity of Inpatient Health Care - between District 